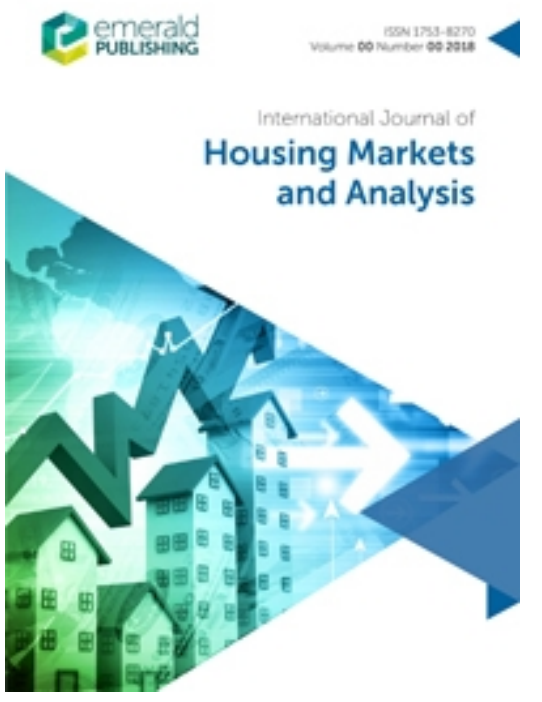

\title{
The Connectedness of House Price Affordability (HPA) and Rental Price Affordability (RPA) Measures
}

\begin{tabular}{|r|l|}
\hline Journal: & International Journal of Housing Markets and Analysis \\
\hline Manuscript ID & IJHMA-03-2021-0029.R1 \\
\hline Manuscript Type: & Research Paper \\
\hline Keywords: & $\begin{array}{l}\text { Housing affordability, Tenure, House Price Affordability, Rental Price } \\
\text { Affordability, Mortgage Rates, New Zealand }\end{array}$ \\
\hline \multicolumn{2}{|l}{} \\
\hline
\end{tabular}

\section{SCHOLARONE \\ Manuscripts}




\title{
The Connectedness of House Price Affordability (HPA) and Rental Price Affordability (RPA) Measures
}

\begin{abstract}
:
The aim of this paper is to examine the relationship between house price affordability (HPA) and rental price affordability (RPA) in New Zealand. The cointegration of HPA and RPA is of particular focus given rising house prices and rising rents. The study examines the lead-lad correlation between house price affordability (HPA) and rental price affordability (RPA). The method uses a generalized least square (GLS) technique and the development of an ordinary least squares (OLS) model. The study shows that there is an existence of cointegration and unidirectional statistical causality effects between HPA and RPA across 11 regions in New Zealand. Furthermore, Auckland, Wellington and Canterbury are the three regions in which the results detect the most extreme effects among HPA and RPA compared to other places in the country. Extended empirical work shows interesting results that there are lead-lag effects of HPA and RPA on each other and on mortgage rates at the national scale. These effects are consistent for both methods but are changed at individual lead-lag variables and among different regions. The study empirically provides useful insight for both academia and practitioners. Particularly in examining the long-run effects, cointegration, and forecasting of the volatile interactions between HPA and RPA.
\end{abstract}

Keywords: Housing Affordability; Tenure; House Price Affordability; Rental Price Affordability; Mortgage Rates 


\section{Introduction}

Housing affordability is one of the most prominent challenges faced by society. The 'dream' of home-ownership by the vast majority of people has become unattainable. Particularly, with house prices out of reach for those without the requisite combination of capital for a deposit, and income to secure and service a mortgage. This has promoted a greater proportion of occupiers 'choosing' to rent rather than purchase a home. As such, there could be a severe problem of rental affordability on the horizon. This study seeks whether the dynamics (of time) of house price affordability (a measure of being able to buy a home) has some sort of cointegration relationship and inferred directional temporal causality with rental price affordability (a measure of being able to rent a home) and vice versa.

The study outlines the literature in the housing affordability field, with specific focus on literature that considers tenure of affordability as owned or rented. Case specific literature in this field within New Zealand is also considered in relation to national-regional matters of tenure affordability. The data sets and collection notes are then put forward, followed by the various methods that have been used to generate significant findings. Explanation of the bootstrap Westerlund (2007) technique to confirm cointegration is provided. Following this is an outline of Dumitrescu and Hurlin's (2012) Granger non-causality panel test on (1) optimal lag length of the global set of regions, and (2) individual regional relationships between house price affordability (HPA) and rental price affordability (RPA). Empirical results are then provided on these tests. Prior to conclusion, there is a discussion of the results, plus some suggestions as to why the statistical cointegrations and causality are occurring.

\section{Literature}

\section{Issues in Housing Affordability}

One of the principle purposes for researching housing affordability is to deal with the problems of inequality in society (Ben-Shahar (2019). Matlack and Vigdor (2008) highlighted that rising house prices do not improve everyone's position, especially given the relationship between income inequality and housing affordability. Quality considerations are also prominent in purpose, particularly given that Lermon and Reeder (1987) observe that in the United States between 1975 and 1983, both affordability ratios and affordability quality measures showed 
growing affordability difficulties. For low-income households it is argued by Wood et al. (2008) that well-being is also under threat given widening housing affordability problems. Moreover, Pollack et al. (2010) also observe that renting rather than owner-occupation heightens health problems of residents when living in unaffordable housing. Housing affordability problems are further highlighted by Linneman and Megbolugbe (1992), as they stress that the issue is often at the top of public policy debate. Noting that housing affordability malaise is partly manufactured by a growing affluent middle-class and affluent young with growing expectations.

Housing affordability study is nothing new, although nations over the last 30 years have experienced higher levels of housing unaffordability. For instance, Gyourko and Linneman (1993) in the United States demonstrate that since the 1960s most of the population are less likely to realise 'the dream' (of owning a home) given the expense of housing. In other structurally different economies such as China, Kuang and Li (2012) give evidence that the affordability issue is becoming increasingly stark in cities, and that since the 1978 economic reforms, households have been encouraged engage with a state supported urban housing market. Voith and Wachter (2009) observe that urban growth is important globally to the housing affordability debate, and that for the United States, housing affordability is becoming a problem for both 'comeback' cities, as well as those continuing on a growth trajectory.

At a global level, commentary by Squires and White (2020) reflect that housing wealth enabled many households to benefit from homeownership as a trade for more debt. Kim and Renaud (2009) recognise that housing affordability is in part driven by global credit expansion and interdependent financial system, and that rising house prices are leading to increased financial risks and volatility for housing. More locally, Bogdon and Can (1997) see housing affordability problems being better solved through policy when supported by spatially disaggregated levels of analysis. Determinants of housing affordability as described by Bramley (1994) bring forward dimensions such as financial deregulation, in addition to demography, income distribution and limited housing supply. Interestingly for this paper, Bramley (1994) sees tenure and housing affordability policy responses becoming more important as owneroccupation affordability problems became more prominent. Baker et al. (2016) present drivers of mobility that can determine the relative affordability of locations. Indeed, for Fisher et al. (2009), they see the relative importance of local amenities of job accessibility, school quality and safety. For households in the United States, Mayer and Engelhardt (1996) present analysis 
that gifts and down-payments are negatively related to income and wealth, and positively related to median house prices.

Planning housing affordability driver considerations are made by Mean and Andrew (2008) where they reveal planning measures solely based on demand formulation of households will miss important quality supply interests, through a combination of new building, conversions, renovations and changes in use. Beer at al. (2007) recognise that planning policies are often directed by neoliberal agendas that do little to halt the difficulty of young and low-income households to access home-ownership or afford rental accommodation. Building restrictions are similarly acknowledged by Glaeser and Gyourko (2003) as impacting on housing affordability, given that building costs in addition to land value have a contribution to house prices.

Measures of housing affordability are wide ranging. Stone (2006) for instance puts forward the case for residual income once all housing costs have been covered by the household. At a similar point in the debate, Kutty (2005) reveal that residual incomes are worsening in the United States and as a result of households are increasingly unable to afford the "poverty basket of non-housing goods'. The use of demand side household expenditure-income ratios are demonstrated by Hulchanski (1995) in terms of defining what housing affordability is in the first place. Definitional measures include clear variables such as household expenditures, and ability to pay the rent and mortgage. But also broader definitional measures in household expenditure-income such as analytical trends, as well as criteria for public housing, housing needs based policy, and institutional criteria for renting or lending (Hulchanski, 1995). On the point of housing, defining and measuring housing need, Whitehead (1991) clearly shows that the measurement path for policy has shifted to affordability rather than needs based. More recently, Gan and Hill (2009) look beyond the median house price metric when looking at housing affordability, by distinguishing between ability to purchase housing and repaying a mortgage loan on housing. Important metrics beyond economics and finance of housing sees Mulliner et al. (2013) apply a sustainable housing affordability multi-criteria model that includes further environmental and social considerations for decision making. 


\section{Tenure Changes - Ownership and Renting}

Housing affordability as a rental tenure issue has become an increasingly debated area. Particularly as Haffner and Boumeester (2010) argue that there has been an increasing income gap between renting and owning, where homeownership is increasingly out of reach for low income households. Hoolachan et al. (2017) demonstrate the point that young people see themselves as a generation of renters rather than owners. McKee et al. (2017) also add to the 'generation rent' research by commenting that ideals of homeownership are in reality unattainable for the majority of young people. Foye et al. (2017) contend that home-ownership as a social norm and positional good (valued by distribution rather than number) increases social well-being at the expense of those renting. Further empirical evidence of homeownership tenure advantages are provided by Sinai and Souleles (2005) when they suggest that for house prices relative to rents, homeownership increases as a financially protective 'hedge' against rental risk.

On the causes of rental affordability, Dong (2018) also argue that in metropolitan areas of the United States, rising income inequality in the 2000s contributed to worsening rental unaffordability for low-income renters. Transport and accessibility determinants as similar to housing price affordability play a part, and for Hong Kong (a city with very high unaffordability ratios) it is argued by Ho and Chiu (2002) that for renters the impact of accessibility on housing affordability is statistically and intuitively significant. Similarly, Revington and Townsend (2016) argue that rental affordability is enhanced near to effective transport, but the results for unaffordable cities of Vancouver and Montreal demonstrate uneven distributions of rental unaffordability, largely illustrating greater private car use and the suburbanisation of poverty. The supply of rental properties also have an effect on rental properties, with an Australian Government commissioned report giving evidence that low income households in cities are struggling to access rental properties because of a lack of supply (Hulse et al, 2015). There is an observation by Collinson (2011) that in the United States between 1990-2009, rental affordability is part encouraged by higher income renters moving into homeownership, and that this is in addition to the rental affordability driver of rising income inequality.

Regional studies of affordability whether house price or rental are not extensively covered in the literature. For this research, the aim is to meet this regional affordability gap whilst further 
considering tenure differences in affordability as applied to New Zealand. For the United Kingdom, Meen (1999) have argued at a regional scale that ripple effects from the South East (including the major conurbation of Greater London) have a regional effect on house prices, and by extension house price affordability. Furthermore, Gray (2012) explores these regional ripple effects in the United Kingdom using disaggregated district scale observations on the housing market. The findings show that there is a regional spatial ripple effect from the South East housing market region over 10 years between 1997-2007, potentially contributing to house price affordability problems. This paper is not directly looking at ripple effects but relative regional differences in house price affordability and rental price affordability.

\section{New Zealand Affordability}

Housing affordability in New Zealand has been discussed in the literature during the 1980s, where Thorns (1988) makes New Zealand comparative analysis with Australia to reiterate the 'old problem' of housing affordability. Two decades later, Thorns (2009) witnesses the affordability problem become more acute in New Zealand, proposing that between 1991-2008 (prior to the global financial crisis) there was a disconnect between market prices and ability for affective policy such as housing allowance subsidies. Post global financial crisis, literature by Murphy (2011) raises affordability concerns when revealing negligible financial and economic impact to Australia and New Zealand, and thus a quick bounce back to continued house price appreciation.

For New Zealand in absolute rather than relative national terms, house price affordability problems have been observed as social and political points for analysis. For instance, Murphy (2014) argues that the affordability metric as applied to New Zealand is unhelpful given its lack of context and constructed to serve global comparisons. Plus, there is an observation that the localised policy responses and process to housing affordability in New Zealand are inherently political (2016). Furthermore, Squires and White (2019) demonstrate that resilience to any housing market affordability problems will tend to favour interests to keep house prices high and affordability low. House price bubbles determined by price dynamics rather than fundamentals are observed for New Zealand between 1970 and 2005, with these inflating house price bubbles signalling that, house price affordability is a globalised house price inflation problem affecting local markets (Fraser et al, 2008). 
Literature in New Zealand at a sub-national scale are made at the city and regional scales. At the city scale, Mattingly and Morrissey (2014) observe different affordability spaces as transport and commuter costs enable unaffordability in wealthier outer suburbs. The case of Auckland is important given the city is the commercial heart of New Zealand and has the greatest proportion of residents. At a regional scale for the focus of this study, more technical analysis has demonstrated that house price affordability has no statistically significant correlation with mortgage rates in a period of continued low interest rates (Squires and Webber, 2019).

The academic literature on rental affordability in New Zealand is limited, although there are some excerpts on inter-tenure debate for this national-regional case study. Hargreaves (2003) suggests that housing tenure choice is to a large degree formulated by income. In that the tenure of choice for New Zealand is predominantly owner-occupation, with private rental tenure choices being determined by an inability to formulate a deposit and service a mortgage. There is a public-practitioner New Zealand book series that include a focus on the growing shift in tenure from owner-occupation to private rent (Eaqub and Eaqub, 2015), and a view on housing tenure change from a public policy lens (Howden-Chapman, 2015). Significant New Zealand national policy documents that have focussed on the housing affordability problem include a recent 'housing stocktake' commissioned by a newly elected Labour-led coalition (Johnson et al, 2018). Plus, a 'housing affordability inquiry' commissioned by the government to the New Zealand Productivity Commission, looking at factors holding back the provision of affordable housing (NZPC, 2012). Social rents have had some attention in New Zealand when looking at alternative hybrid public-private tenure approaches using quasi-market financial instruments (Dykes, 2018). This hybrid approach may become more important as it has been documented that the social rented housing sector in New Zealand has changed orientation many times between the state and market (Murphy, 2004). For the purposes of this research, the focus is on the private rental tenure and its affordability relative to income.

\section{Data and Methodology}

Data

Data were sourced from several secondary sources for quarterly observations between Q22000 and Q2-2019 (noting q1-2000 to q4-2017 for the graph trends - Figure 2 and 3) 
corresponding to each of the New Zealand's eleven regional geographies including Auckland, Canterbury, Hawke's Bay, Manawatu, Nelson, Northland, Otago, Southland, Otago, Southland, Taranaki, Waikato, and Wellington. The regional collection of data has taken into account 'collapsed-merged' and largely immaterial boundary changes at the regional level for the purposes of this study. The majority of boundary changes were in the final year (March 2019) of the 20 year quarterly dataset. Boundary changes are an inevitable difficulty given data providers' own purposes, although for this study the 11 regions are a very useful set that span 20 years to maximise the lead-lag effects (Table 1, and Figure 1). Rather than getting more strictly bounded geographies for say 4 years. The merged data set has also benefitted by including all of the observations rather than using a sample.

Table 1: Data Collection Collapsed-Merged Regions to maximise the 20-year span Source: Authors

\begin{tabular}{|c|c|c|}
\hline $\begin{array}{l}16 \text { Regions - Collected After } \\
\text { March } 2019\end{array}$ & $\begin{array}{l}12 \text { Regions - Collected Before } \\
\text { March } 2019\end{array}$ & $\begin{array}{l}11 \text { Regions Used for This Research - } \\
\text { Q2-2000 and Q2-2019 }\end{array}$ \\
\hline 1. Northland & 1. Northland & 1. Northland \\
\hline 2. Auckland & 2. $\quad$ Auckland & 2. Auckland \\
\hline 3. Waikato & \multirow{3}{*}{$\begin{array}{l}\text { 3. Waikato: } \\
\text { Waikato/Bay of Plenty/Gisborne }\end{array}$} & \multirow{3}{*}{$\begin{array}{c}\text { 3. Waikato: } \\
\text { Waikato/Bay of Plenty/Gisborne }\end{array}$} \\
\hline 4. Bay of Plenty & & \\
\hline 5. Gisborne & & \\
\hline 6. Hawke's Bay & 4. Hawke's Bay & 4. Hawke's Bay \\
\hline 7. Manawatu/Whanganui & $\begin{array}{c}\text { 5. Manawatu: } \\
\text { Manawatu/Whanganui }\end{array}$ & $\begin{array}{c}\text { 5. Manawatu: } \\
\text { Manawatu/Whanganui }\end{array}$ \\
\hline 8. Taranaki & 6. Taranaki & 6. Taranaki \\
\hline 9. Wellington & 7. Wellington & 7. Wellington \\
\hline 10. Tasman & \multirow[b]{3}{*}{ Nelson/Marlborough/Tasman } & \multirow[b]{3}{*}{ Nelson/Marlborough/Tasman } \\
\hline 11. Nelson & & \\
\hline 12. Marlborough & & \\
\hline 13. West Coast & \multirow{2}{*}{$\begin{array}{c}\text { 9. Canterbury: } \\
\text { Canterbury/West Coast }\end{array}$} & \multirow{2}{*}{$\begin{array}{c}\text { 9. Canterbury: } \\
\text { Canterbury/West Coast }\end{array}$} \\
\hline 14. Canterbury & & \\
\hline \multirow[t]{2}{*}{ 15. Otago } & 10. Otago & \multirow[t]{2}{*}{ 10. Otago } \\
\hline & 11. Central Otago Lakes & \\
\hline 16. Southland & 12. Southland & 11. Southland \\
\hline
\end{tabular}




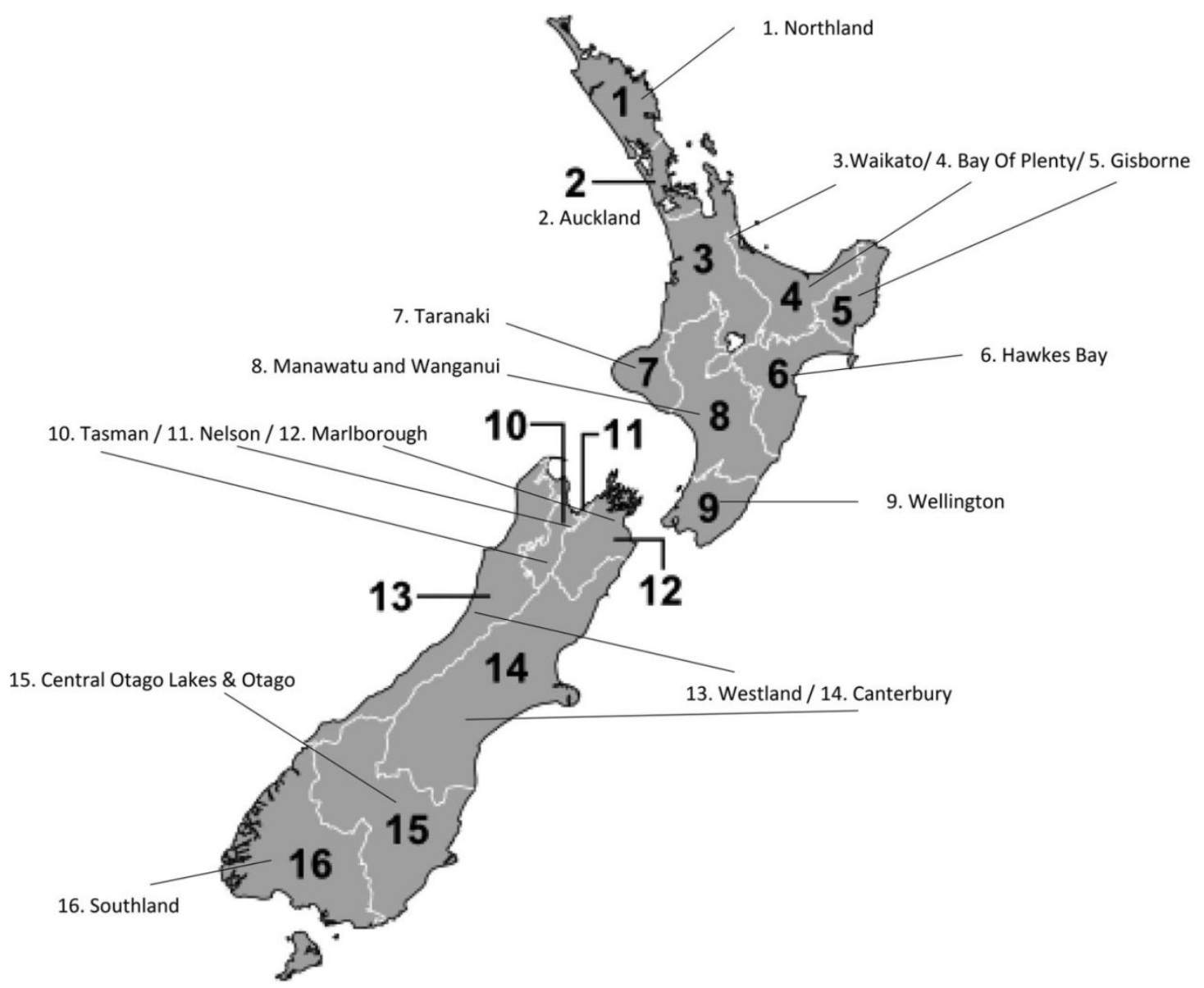

Figure 1: New Zealand's 16 (Collapsed to 11) regional boundaries used for analysis Source: Authors

Regional median house price data were collected by REINZ (Real Estate Institute New Zealand) from sales agencies that are instructed to record sales transaction data ${ }^{1}$ in the second month in the quarter (e.g. February for quarter 1). Rental data at regional level is sourced from MBIE (Ministry for Business Innovation and Employment) who provide weekly rental prices at the point when the landlord lodges a bond deposit with the government authority on behalf of the tenant. As with the regional median house price, the rental price data is recorded for the second month in the quarter. Wage data are sourced from Statistics New Zealand (SNZ) as weekly wages, and similarly are recorded in the second month of each quarter.

1 Local authorities also separately and commercially outsource the recording of sales information on sales transactions for public purposes. The study uses REINZ data given the researchers access to this dataset. 


\section{Methodology}

The study here, is mostly interested in the statistical relationship and statistical causality between the affordability of house purchase prices and the affordability of house rental prices. To set this technical focus in a broader research design several aspects were incorporated. Firstly, the 'real world' or applied nature of the subject matter meant that a critical realist philosophical perspective could be taken (Archer et al., 2013). Interpreted here as a nondogmatic approach, ontological aspects of the philosophy are to (1) celebrate the existence of reality independent of human consciousness; and (2) ascribe causal powers to human reasons and social structures (Bhaskar, 2016). As such, the search for affordability in statistical relationships and statistical causes can be revealed to match independent 'truths' and 'reality' of housing affordability. Plus the ontology in this study is part of well ingrained socialeconomic structural powers centred on ownership-rental tenure, wages and interest rates. For epistemological aspects that relate to the nature of knowledge, two key features are also recognised in critical realism, these are to: (1) reject relativism in social and scientific discourses; and (2) re-orientate the social sciences towards its emancipatory goals (Sayer, 1994). For this study, the approach in uncovering relationships can still reject relativism and move to embrace social and economic emancipatory progress. The reason being that statistical relationships and statistical causality can to some degree infer and support arguments as to 'why' there is more absolute and acute problems of house price affordability and rental price affordability. The debate as to differences in statistical and intuitive causality is clearly for another paper and wider methodological debate.

More technically, in order to facilitate an analysis of the interregional variation in these housing affordability variables, the study needs to control for local wage rates (rather than local consumer price variation). Due to the possibility of particular regions experiencing purchases of properties as second homes by people resident in other regions (or even from overseas), and that this spatial effect in the purchasing of second homes is neither uniform across regions not uniform over time, the approach was to construct affordability ratios whereby there is a division between each region's house price $(h p)$ and house rental $(h r)$ indicator by the regional wage $(w)$ within the region $(i)$ at time $(t)$, such that: 


$$
H P A=\frac{h p_{i t}}{w_{i t}}
$$

and

$$
H R A=\frac{h r_{i t}}{w_{i t}}(2)
$$

where $H P A$ and $H R A$ are the house price affordability and house rental affordability variables respectively.

The study recognises that the denominators cancel out when equating $H R A$ and $H P A$, thereby simplifying the relation to $h p_{i t} / h r_{i t}$, but this would be at a cost of the following intuitively useful information. First, it is acknowledged that house ownership and rental prices increase at an increasing rate, simply because a percentage increase in the current price is a compound increase on a previous increase, but wages also increase at a compound rate. As second homes tend to be purchased in a different region, an increase in wages in one region (or country) - which may lead to a second home purchase in another region - may be behind the decrease in affordability in a different New Zealand region. Second, it is worth considering price data relative to the current and regional ability to make that purchase, so not considering wage data precludes that discussion. Third, the study has a particular interest in whether house prices are becoming increasingly unaffordable in different regions at different rates, and therefore the discussion is about the regional wage rate.

To gauge a first impression of the affordability data, consider Figures 2 and 3 which present line graphs of house rental price and regional house price affordability data over time respectively. Improvements in affordability would be illustrated by a fall in the line. The rental affordability graph shows that rental values are on average about 25 percent of people's incomes, but this varies across regions and over time from a low of 15 percent in Southland in 2001 to a high of 41 percent in Auckland in 2017. In comparison, the house price affordability graph shows that house prices were on average four times the average median wage rising to an average of about seven times the average monthly median wage, but again this varies across regions and over time from a low of about one and a half times average median wages in Southland in 2001 to a high of thirteen times average median wages in Auckland in 2017.

Figure 2: Regional Rental Price Affordability 


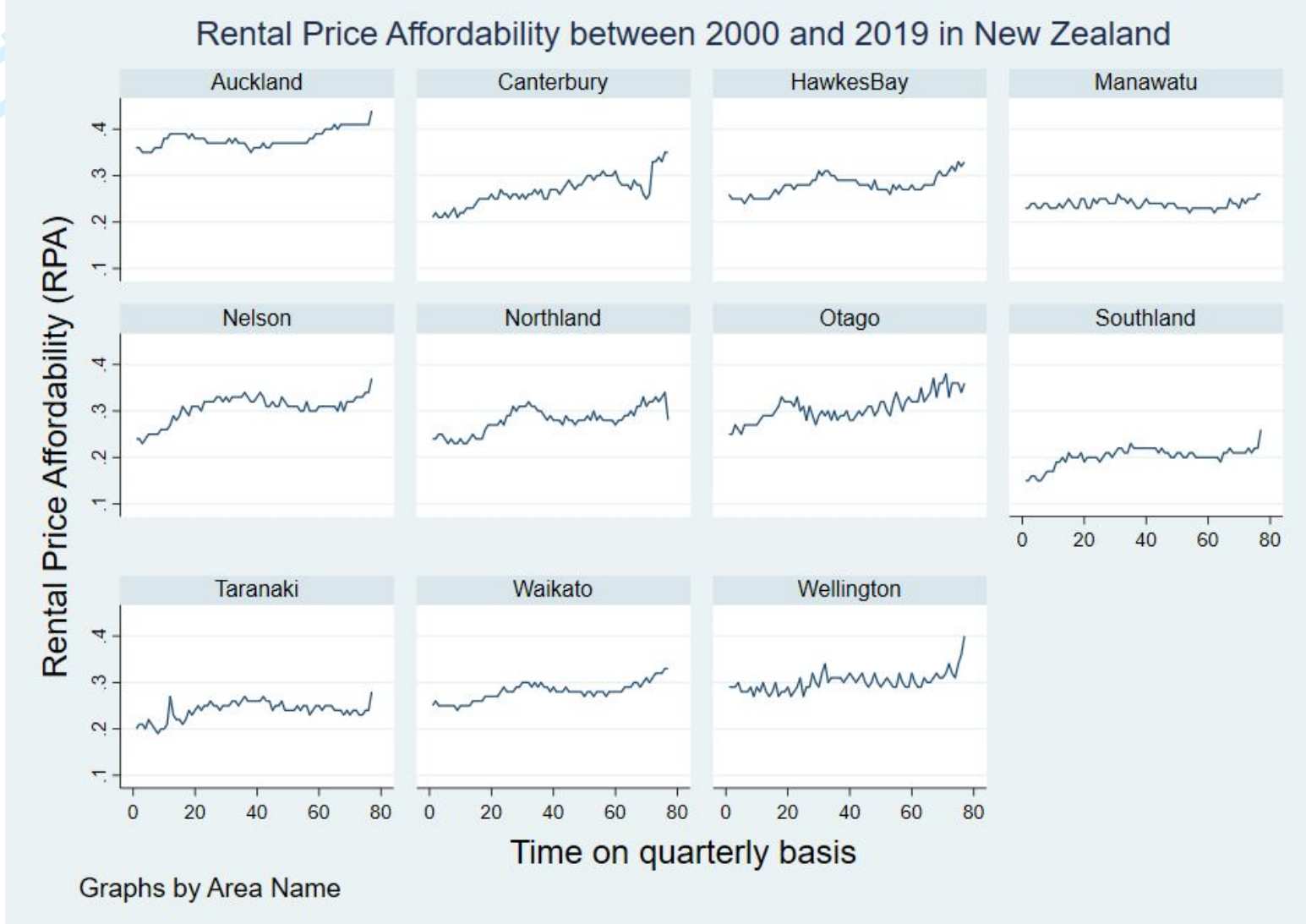

Source: Authors' Calculations

Figure 3: Regional House Price Affordability 


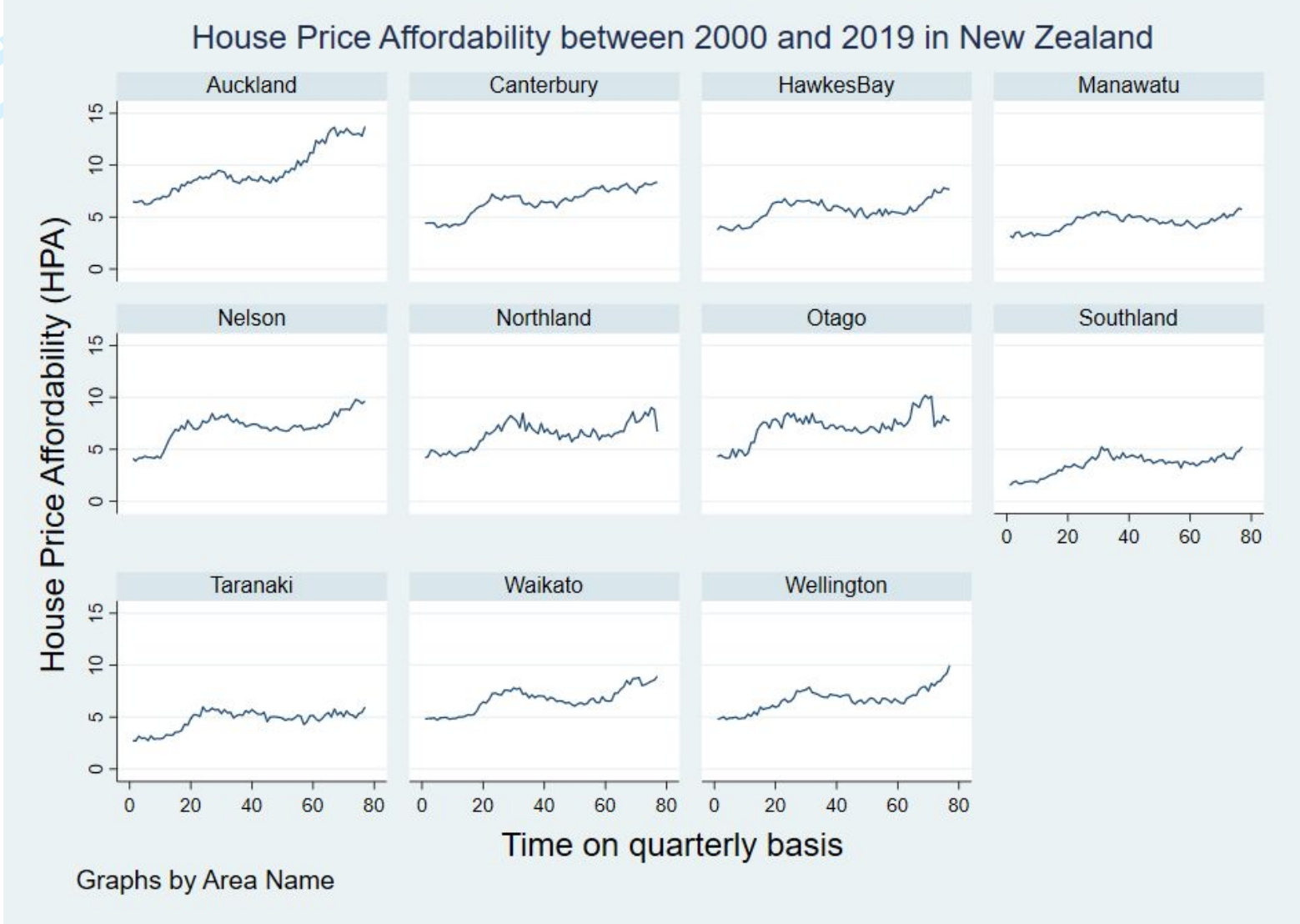

Source: Authors' Calculations

There are important similarities and differences between these graphs. Both graphs emphasise that the affordability is a greatest problem in Auckland, where rental affordability started about 35 percent of average median incomes in 2001 rising to more than 40 percent in 2017 and where house price affordability has been accelerating very fast from 2012 onwards. The house rental affordability indices display a slight upward trend, although this is more pronounced for Southland, Canterbury, Taranaki, and Otago than for Manawatu, Nelson and Wellington. In comparison, house price affordability data display a clear cyclical pattern, with fast increases until the recession associated with the global financial crisis, a flat-lining and even a slight improvement in affordability for the following four to five years, and then a further increase in the slope. 
Unit Root Tests

Table 2: Levin-Lin-Chu unit root test

\begin{tabular}{lccccc}
\hline \multirow{2}{*}{ Variable } & \multicolumn{2}{c}{ No trend } & \multicolumn{2}{c}{ With trend } & Integration order \\
& Level & First difference & Level & First difference & \\
\hline \multirow{2}{*}{$H P A$} & -1.2568 & $-28.8235^{* * *}$ & -0.7092 & $-29.5598^{* * *}$ & Unit root at $I(0)$ \\
& $(0.1044)$ & $(0.0000)$ & $(0.2391)$ & $(0.0000)$ & Stationary at first difference $I(1)$ \\
\multirow{2}{*}{$R P A$} & $-2.2517^{* *}$ & $-3.4269^{* * *}$ & -0.4003 & $-3.1547^{* * *}$ & Unit root at $I(0)$ \\
& $(0.0122)$ & $(0.0003)$ & $(0.3445)$ & $(0.0008)$ & Stationary at first difference $I(1)$ \\
\hline
\end{tabular}

Source: Authors' Calculations

Prior to estimating empirical models, the study technique uses Levin-Lin-Chu (2002) biasadjusted unit root tests to identify whether the data is stationary or trend stationary, and with this test the null hypothesis is that the series contains a unit root with the alternative being that the series is stationary. This is an important initial phase of any empirical estimation because if a variable contains a stochastic component (a unit root) with respect to its longitudinal metric, which in this case is time, then regression analysis of the variable will lead to a spurious regression result.

The study then estimates the Levin-Lin-Chu bias-adjusted unit root tests for both variables with and without a trend in order to identify the order of integration. The test involves fitting an augmented Dickey-Fuller regression for each panel (Leybourne, 1995); to estimate the long-run variance of each series the approach use the default of 13 lags as elected by the method proposed by Levin, Lin and Chu. The results presented in Table 2 show that the two variables have a unit root in levels with the trend and the HPA variable has a unit root in the level with no trend. The test identifies that the $R P A$ variable is stationary in the level with no trend but this is only statistically significant at the $5 \%$ level. The coefficient of the first difference of the HPA variable $(-28.8235)$ is significantly less than zero $(\mathrm{p}<0.0000)$, so there is a rejection of the null hypothesis of a unit root in favour of the alternative that the first difference of $H P A$ is stationary. The same result applies for $R P A$. For consistency, and by relying on statistical significance at the $1 \%$ level, the approach is to use the data in subsequent analyses only after the data are first differenced, as there is a high level of statistical confidence that the variables are not only consistent in their definition but also are stationary.

Error correction-based panel cointegration tests

Application of the Levin-Lin-Chu test above confirms that the series are stationary after first differencing, and this enables the use of the Westerlund and Persyn (2007) cointegration test 
which assumes that all unit roots should integrated of order one. Based on the eoor correction model (ECM), The approach of Westerlund (2007) generates four tests of panel cointegrations including $G_{t}, G_{a}$, and $P_{t}, P_{a}$. The first two panel $G_{t}$ and $G_{a}$ tests are implemented to examine the alternative hypothesis that whether there is a cointegration for at least one cross-section, while the other two panel $P_{t}$ and $P_{a}$ are conducted to examine whether there is a cointegration for the whole panel.

The Westerlund and Persyn (2008)'s panel cointegration approach is applied to identify whether their stationary linear combination of the two variables and essentially test whether error-correction is present for individual regions and for the whole panel. The ECM's dataestimating procedure for the Error Correction (EC) term enables deterministic different components and justifies cross-sectional dependencies and serial correlation in the error term. Therefore, to ensure that the cross-sectional units are not strongly affected by common factors, the study bootstrapped robust critical values for the test statistics. The bootstrapped distribution allows the generation of p-values in detecting cross-sectional correlation. $G_{a}$ and $P_{a}$ estimations are adjusted standard errors regarding Newey and West (1994) for heteroskedasticity, while $G_{t}$ and $P_{t}$ are estimated based on the intercept term's standard errors following a standard technique.

\section{Granger non-causality test}

If there is a presence of long-term relation between RPA and HPA, there is an implication that there is statistical causality for one direction at least (Granger, 2003). For detecting the causality direction, the study employs the Granger non-causality estimation method developed by Dumitrescu and Hurlin (2012) that fits heterogeneity and cross-sectional dependence (CSD). This method is invented based on Granger (1969)'s hypothesis of non-causality in a heterogeneous pooled cross-sectional data. Regarding Dumitrescu and Hurlin (2012), for each region $i=$ Auckland, ......, Wellington at time $t=1, \ldots, \mathrm{T}$, a test of causality in the panel based on individual Wald statistic of the averaged Granger non-causality across the cross-sectional units. The method considers the causality's heterogeneity and the regression model's heterogeneity in terms of testing process for Granger causality. 


\section{Regression Models}

Besides the implementation of unit root tests (Levin et al., 2002), error correction-based panel cointegration tests (Westerlund, 2007) and the Granger non-causality tests (Dumitrescu and Hurlin, 2012). The study is extended further by examining the relation between Rental Price Affordability (RPA) and House Price Affordability (HPA) through using the generalized least squares (GLS) regression as an extension of the classical linear regression model (CLRM). As the CLRM's assumption is that the error variance is homoscedastic and that there is no autocorrelation among the error term where $y=\beta X+u$ in which $\operatorname{cov}\left(u u^{\prime}\right)=\sigma^{2} I$ called as the scaler covariance matrix. However, this assumption might not be appropriate for all cases. For instance, there is the potential to face a problem of heteroscedasticity when dealing with crosssectional data and autocorrelation with time-series data. As such, there is the potential to face both these problems when working with pooled cross-sectional data.

To mitigate the heteroscedasticity and autocorrelation problems, the approach is to inspect an alternative form of covariance matrix as $\operatorname{cov}\left(u u^{\prime}\right)=\sigma^{2} V$ in which $V$ is not considered as an identity matrix, hence permitting heteroscedasticity and autocorrelation considered as the nonscalar covariance form. Therefore, the GLS method is invented to deal with the non-scalar covariance matrix as an extension of CLRM method (Gujarati, 2019).

\section{GLS Regression Model of Rental Price Affordability (RPA):}

The study uses techniques to estimate the relation between RPA, HPA, and mortgage rate. In doing so, there is also a focus on the lead-lag effects among variables. In doing so, the proposition is via the following regression model of RPA:

$R P A_{i, t}$

$$
\begin{aligned}
& =\alpha+\beta_{1} R P A_{t-1}+\beta_{2} R P A_{t+1}+\beta_{3} H P A_{t}+\beta_{4} H P A_{t-1}+\beta_{5} H P A_{t+1}+\beta_{6} \text { Mortgage }_{t}+\beta_{7} \\
& \text { Mortgage }_{t-1}+\beta_{8} \text { Mortgage }_{t+1}+\varphi^{\prime} \text { Region }+\omega^{\prime} \text { Time }+u_{i, t}
\end{aligned}
$$

Where $i$ and $t$ indicate region $i$ at time $t . R P A_{i, t}$ is the dependent variable for rental price affordability measure. The study controls for a vector of independent variables including lagged-one rental price affordability $\left(R P A_{t-1}\right)$, lead-one rental price affordability $\left(R P A_{t+1}\right.$ ), house price affordability $\left(H P A_{t}\right)$, lagged-one house price affordability $\left(H P A_{t-1}\right)$, lead-one 
house price affordability $\left(H P A_{t+1}\right)$, mortgage rate $\left(M o r t g a g e_{i, t}\right)$, lagged-one mortgage rate $\left(\right.$ Mortgage $\left._{i, t-1}\right)$, lead-one mortgage rate $\left(\right.$ Mortgage $\left._{i, t-1}\right)$. The study controls for region effects ( $\varphi^{\prime}$ Region) and time effects ( $\omega^{\prime}$ Time), respectively.

\section{GLS regression model of House Price Affordability (HPA)}

The study applies the same procedure above for house price affordability (HPA) controlling for the similar set of dependent variables investigating the lead-lag effects among independent variables on house price affordability. The study proposes the regression model of HPA as follows:

$$
\begin{aligned}
H P A_{i, t} & \\
& \alpha+\beta_{1} H P A_{t-1}+\beta_{2} H P A_{t+1}+\beta_{3} R P A_{t}+\beta_{4} R P A_{t-1}+\beta_{5} R P A_{t+1}+\beta_{6} \\
& \text { Mortgage } e_{t}+\beta_{7} \text { Mortgage }_{t-1}+\beta_{8} \text { Mortgage }_{t+1}+\varphi^{\prime} \text { Region }+\omega^{\prime} \text { Time } \\
& +u_{i, t} \text { (4) }
\end{aligned}
$$

The characters of $i$ and $t$ present region $i$ at time $t$. The dependent variable is house price affordability measure $H P A_{i, t}$. The vector of control variables includes lagged-one house price affordability $\left(H P A_{t-1}\right)$, lead-one house price affordability $\left(H P A_{t+1}\right)$, lagged-one rental price affordability $\left(R P A_{t-1}\right)$, lead-one rental price affordability $\left(R P A_{t+1}\right)$, mortgage rate $\left(\right.$ Mortgage $\left._{i, t}\right)$, lagged-one mortgage rate (Mortgage $\left.e_{i, t-1}\right)$, lead-one mortgage rate ( Mortgage $_{i, t-1}$ ). Similarly, the first run a GLS regression model with random effects is presented in Table 8 Column 1. The study then controls for region effects ( $\varphi^{\prime}$ Region) and time effects ( $\omega^{\prime}$ Time $)$ presented in Column 2 and 3, respectively. There is an inclusion of both regional and time fixed effects as presented in Column 4.

\section{Empirical Results}

The empirical results are presented as follows. Table 3 presents descriptive statistics. Table 4 is the matrix of correlation. Table 5 presents Levin-Lin- Chu unit root test. Table 6 reports Westerlund error correction model panel cointegration tests. Table 7 presents Dumistrescu and Hurlin's (2012) Granger non-causality test. Table 8 Panel A and B report regression results of rental price affordability (RPA) and housing price affordability (HPA), respectively. 
Summary Statistics

Table 3: Summary statistics

\begin{tabular}{|c|c|c|c|c|c|c|c|c|}
\hline \multicolumn{9}{|c|}{ Panel A: Full sample [2000-2019] } \\
\hline Variable & $\mathrm{N}$ & Mean & p25 & Median & p75 & Min & Max & Std. Dev \\
\hline Area ID & 847 & 6.000 & 3.000 & 6.000 & 9.000 & 1.000 & 11.000 & 3.164 \\
\hline Time & 847 & 40.000 & 21.000 & 40.000 & 59.000 & 2.000 & 78.000 & 22.239 \\
\hline Mortgage rate & 847 & 6.742 & 5.560 & 6.730 & 7.630 & 4.780 & 9.620 & 1.259 \\
\hline RPA & 847 & 0.280 & 0.250 & 0.280 & 0.310 & 0.150 & 0.440 & 0.050 \\
\hline HPA & 847 & 6.221 & 4.840 & 6.360 & 7.380 & 1.510 & 13.730 & 1.969 \\
\hline D1hpa & 847 & 0.053 & -0.160 & 0.040 & 0.280 & -2.890 & 1.540 & 0.374 \\
\hline D1rpa & 847 & 0.001 & -0.010 & 0.000 & 0.010 & -0.060 & 0.070 & 0.012 \\
\hline
\end{tabular}

\begin{tabular}{lcrrrrr}
\hline \multicolumn{1}{c}{ Panel B: By region } & \multicolumn{2}{c}{ Region } \\
\cline { 2 - 7 } \multicolumn{1}{c}{ RPA } & \multicolumn{2}{c}{ Mean } & Std. Dev & Mer. Dev & Mean & Std. Dev \\
\hline Auckland & 0.379 & 0.019 & 9.439 & 2.187 & 6.742 & 1.266 \\
Canterbury & 0.267 & 0.033 & 6.511 & 1.285 & 6.742 & 1.266 \\
Hawke's Bay & 0.279 & 0.021 & 5.681 & 1.032 & 6.742 & 1.266 \\
Manawatu & 0.2383 & 0.009 & 4.499 & 0.743 & 6.742 & 1.266 \\
Nelson & 0.306 & 0.028 & 7.088 & 1.428 & 6.742 & 1.266 \\
Northland & 0.281 & 0.028 & 6.435 & 1.224 & 6.742 & 1.266 \\
Otago & 0.307 & 0.030 & 7.155 & 1.391 & 6.742 & 1.266 \\
Southland & 0.202 & 0.020 & 3.571 & 0.932 & 6.742 & 1.266 \\
Taranaki & 0.240 & 0.019 & 4.728 & 0.948 & 6.742 & 1.266 \\
Waikato & 0.281 & 0.020 & 6.668 & 1.160 & 6.742 & 1.266 \\
Wellington & 0.301 & 0.021 & 6.662 & 1.089 & 6.742 & 1.266 \\
& & & & & &
\end{tabular}

The descriptive statistics of the selected variables are presented for the full sample in Table 1 Panel A and by regions in Panel B. The research sample includes 11 regions in New Zealand as detailed in Table 1 for the period 2000-2019. A presented in Panel A, housing price affordability has a mean value of $6.2 \%$ ranging from a minimum value of $1.5 \%$ to the maximum value of $13.7 \%$ with a standard deviation of $1.96 \%$, while rental price affordability is ranged from $0.15 \%$ to $0.44 \%$ with a mean value of $0.28 \%$ over the last twenty years in the country. As presented in Panel B, the summary statistics show that given the same average value of $6.74 \%$ in mortgage rate, the rental price affordability and house price affordability are changed at different levels over the past twenty years. Auckland, Otago and Canterbury 


\section{Levin-Lin-Chu Unit Root Test Results}

Table 5: Levin-Lin-Chu unit-root test

\begin{tabular}{|c|c|c|c|c|}
\hline \multirow[t]{2}{*}{ HPA } & \multicolumn{2}{|c|}{ No trend (1) } & \multicolumn{2}{|c|}{ With trend (2) } \\
\hline & Statistic & p-value & Statistic & $\mathrm{p}$-value \\
\hline Unadjusted $\mathrm{t}$ & -3.7680 & & -6.6349 & \\
\hline Adjusted $t^{*}$ & 0.2889 & 0.6137 & 0.3931 & 0.6529 \\
\hline RPA & Statistic & p-value & Statistic & $\mathrm{p}$-value \\
\hline Unadjusted $\mathrm{t}$ & -3.5186 & & -6.826 & \\
\hline Adjusted t & 2.3182 & 0.9898 & 2.9431 & 0.9984 \\
\hline ADF regressions (lags average) & 2.45 & 2.91 & 2.73 & 6.00 \\
\hline AR parameter & \multicolumn{4}{|c|}{ Common } \\
\hline Panel means & \multicolumn{4}{|c|}{ Included } \\
\hline Number of panels & \multicolumn{4}{|c|}{11} \\
\hline Number of periods & \multicolumn{4}{|c|}{77} \\
\hline Ho: & \multicolumn{3}{|c|}{ Panels contain unit roots } & 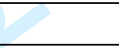 \\
\hline Ha: & \multicolumn{4}{|c|}{ Panels are stationary } \\
\hline
\end{tabular}

The study obtains a panel data on house price affordability (HPA) and rental price affordability (RPA) for 11 regions in New Zealand for the period 2000-2019 on quarterly basis. Further, the 
study employs Levin-Lin-Chu (2002)'s unit root test to a sample of 11 regions in New Zealand to validate whether RPA and HPA include a unit root presented in Table 5. The panel data contains 11 panels and 77 periods. The null hypothesis is that the panels contain unit roots and the alternative hypothesis is that the panels are stationary. The Levin-Lin-Chu (LLC) unit root test supposes that all panels contain a common autoregressive (AR) parameter. Table 5 Column 1 indicates the unit root test with panel means and no time trend that expects the time periods grow faster than number of panels, while column 2 includes a time trend. The LLC test entails fitting an augmented Dickey-Fuller (ADF) regression for each panel; with the number of lags to be included with at most 10 lags based on the AIC. For HPA and RPA, the LLC adjusted $t$ statistics are 0.2889 and 2.3182 which are insignificant for all the levels of usual testing $(\mathrm{p}>0.00005)$. Therefore, the study accepts the null hypothesis and conclude that the panels contain unit root. Findings also show that the test statistics are insignificant for both HPA and RPA. The unadjusted $t$ denotes a conventional $t$ statistic to test the null hypothesis $\left(H_{0}\right) \Phi=0$.

\section{Error Correction Model Panel Cointegration Results}

Table 6: Westerlund error correction model panel cointegration tests

\begin{tabular}{|c|c|c|c|c|c|}
\hline & Statistics & Value & Z-value & P-value & Robust P-value \\
\hline \multirow{4}{*}{$\begin{array}{l}\text { Whole } \\
\text { panel }\end{array}$} & $\mathrm{Gt}$ & -8.301 & -24.082 & 0.000 & 0.000 \\
\hline & $\mathrm{Ga}$ & -114.429 & -65.365 & 0.000 & 0.000 \\
\hline & $\mathrm{Pt}$ & -28.026 & -23.559 & 0.000 & 0.000 \\
\hline & $\mathrm{Pa}$ & -121.176 & -87.367 & 0.000 & 0.000 \\
\hline \multirow{4}{*}{ Auckland } & $\mathrm{Gt}$ & -6.291 & -5.023 & 0.000 & 0.000 \\
\hline & $\mathrm{Ga}$ & -65.978 & -10.808 & 0.000 & 0.000 \\
\hline & $\mathrm{Pt}$ & -6.291 & -4.871 & 0.000 & 0.000 \\
\hline & $\mathrm{Pa}$ & -65.978 & -13.909 & 0.000 & 0.000 \\
\hline \multirow{4}{*}{ Northland } & $\mathrm{Gt}$ & -6.919 & -5.723 & 0.000 & 0.000 \\
\hline & $\mathrm{Ga}$ & -114.612 & -19.742 & 0.000 & 0.000 \\
\hline & $\mathrm{Pt}$ & -6.919 & -5.503 & 0.000 & 0.000 \\
\hline & $\mathrm{Pa}$ & -114.612 & -24.864 & 0.000 & 0.000 \\
\hline \multirow{4}{*}{ Otago } & $\mathrm{Gt}$ & -9.251 & -8.318 & 0.000 & 0.000 \\
\hline & $\mathrm{Ga}$ & -160.426 & -28.158 & 0.000 & 0.000 \\
\hline & $\mathrm{Pt}$ & -9.251 & -7.848 & 0.000 & 0.000 \\
\hline & $\mathrm{Pa}$ & -160.426 & -35.183 & 0.000 & 0.000 \\
\hline \multirow{4}{*}{ Waikato } & $\mathrm{Gt}$ & -8.535 & -7.521 & 0.000 & 0.000 \\
\hline & $\mathrm{Ga}$ & -105.489 & -18.066 & 0.000 & 0.000 \\
\hline & $\mathrm{Pt}$ & -8.535 & -7.128 & 0.000 & 0.000 \\
\hline & $\mathrm{Pa}$ & -105.489 & -22.809 & 0.000 & 0.000 \\
\hline \multirow{4}{*}{ Hawkes's Bay } & $\mathrm{Gt}$ & -7.566 & -6.443 & 0.000 & 0.000 \\
\hline & $\mathrm{Ga}$ & -115.911 & -19.981 & 0.000 & 0.000 \\
\hline & $\mathrm{Pt}$ & -7.566 & -6.154 & 0.000 & 0.000 \\
\hline & $\mathrm{Pa}$ & -115.911 & -25.156 & 0.000 & 0.000 \\
\hline \multirow{4}{*}{ Taranaki } & $\mathrm{Gt}$ & -8.548 & -7.536 & 0.000 & 0.000 \\
\hline & $\mathrm{Ga}$ & -93.450 & -15.855 & 0.000 & 0.000 \\
\hline & $\mathrm{Pt}$ & -8.548 & -7.142 & 0.000 & 0.000 \\
\hline & $\mathrm{Pa}$ & 93.450 & -20.097 & 0.000 & 0.000 \\
\hline
\end{tabular}




\begin{tabular}{cccccc}
\hline \multirow{3}{*}{ Manawatu } & $\mathrm{Gt}$ & -8.774 & -7.787 & 0.000 & 0.000 \\
& $\mathrm{Ga}$ & -132.412 & -23.012 & 0.000 & 0.000 \\
& $\mathrm{Pt}$ & -8.774 & -7.369 & 0.000 & 0.000 \\
& $\mathrm{~Pa}$ & -132.412 & -28.873 & 0.000 & 0.000 \\
\hline \multirow{3}{*}{ Wellington } & $\mathrm{Gt}$ & -10.714 & -9.947 & 0.000 & 0.000 \\
& $\mathrm{Ga}$ & -171.316 & -30.159 & 0.000 & 0.000 \\
& $\mathrm{Pt}$ & -10.714 & -9.320 & 0.000 & 0.000 \\
& $\mathrm{~Pa}$ & -171.316 & -37.636 & 0.000 & 0.000 \\
\hline \multirow{3}{*}{ Nelson } & $\mathrm{Gt}$ & -10.101 & -9.265 & 0.000 & 0.000 \\
& $\mathrm{Ga}$ & -111.462 & -19.163 & 0.000 & 0.000 \\
& $\mathrm{Pt}$ & -10.101 & -8704 & 0.000 & 0.000 \\
& $\mathrm{~Pa}$ & -111.462 & -24.154 & 0.000 & 0.000 \\
\hline \multirow{5}{*}{ Canterbury } & $\mathrm{Gt}$ & -6.288 & -5.021 & 0.000 & 0.000 \\
& $\mathrm{Ga}$ & -76.896 & -12.814 & 0.000 & 0.000 \\
& $\mathrm{Pt}$ & -6.288 & -4.869 & 0.000 & 0.000 \\
& $\mathrm{~Pa}$ & -76.896 & -16.368 & 0.000 & 0.000 \\
\hline \multirow{5}{*}{ Southland } & $\mathrm{Gt}$ & -8.324 & -7.287 & 0.000 & 0.000 \\
& $\mathrm{Ga}$ & -110.763 & -19.035 & 0.000 & 0.000 \\
& $\mathrm{Pt}$ & -8.324 & -6.917 & 0.000 & 0.000 \\
& $\mathrm{~Pa}$ & -110.763 & -23.997 & 0.000 & 0.000 \\
\hline
\end{tabular}

Notes: Models contain 1 lag and 1 lead and are estimated with 100 bootstrap iterations. This used the Alkaline Information Criterion to determine the lag length for each series using the Bartlett kernel window width. Nonbootstrapped Z-value and the robust corresponding p-values are presented as one-sided test in the case of there is no cross-sectional dependence. The statistics of $\mathrm{z}$-values and $\mathrm{p}$-values are estimated based on a normal distribution using 100 bootstrapping regression simulation to mitigate statistical bias.

Table 6 present Westerlund (2007)'s error correction-based panel cointegration (WECPC) test results globally for all the regions, and for each region in New Zealand. The study applies this test to detect the presence of cointegration between HPA and RPA. The existence of the cointegration facilitates the equilibrium between RPA and HPA in the long-term. The results of the WECPC test are presented in Table 6 showing four statistics. At the region-level, the statistics of $G_{t}$ and $G_{a}$ are exhibited. At the panel level, the statistics of $P_{t}$ and $P_{a}$ are provided. For the statistics of p-values, there is a rejection of the null hypothesis of non-cointegration across all the regions at $1 \%$ significance level indicating that there is a existence of strong cointegration between HPA and RPA in New Zealand. The results presented in Table 6 denote unidirectional Granger causality moving from HPA to RPA across all regions at the 1\% significance level at both individual region and panel levels.

Granger Non-Causality Test Results

Table 7: Dumitrescu and Hurlin's (2012) Granger non-causality test

\begin{tabular}{|c|c|c|c|c|}
\hline (2) & $\begin{array}{c}\text { Lag } \\
\text { order }\end{array}$ & W-bar & Z-bar & Z-bar tilde \\
\hline \multicolumn{5}{|c|}{ H0: D1HPA does not Granger-cause D1RPA } \\
\hline Whole sample & 1 & 6.7717 & $13.5358 * * *$ & 12. \\
\hline Wellington & 3 & 25.6273 & $9.2375^{* * *}$ & $8.5908^{* * *}$ \\
\hline
\end{tabular}




$\begin{array}{llccc}\text { Auckland } & 3 & 10.9056 & 3.2274 * * & 2.9786^{* *} \\ \text { Canterbury } & 1 & 10.2481 & 6.5394 * * & 6.2073^{* *} \\ \text { Nelson } & 2 & 4.1603 & 1.0802 & 0.9911 \\ \text { Hawke's Bay } & 1 & 7.0451 & 4.2746^{*} & 4.0509^{*} \\ \text { Otago } & 4 & 4.4225 & 0.1494 & 0.0958 \\ \text { Northland } & 1 & 3.0580 & 1.4553 & 1.3666 \\ \text { Waikato } & 1 & 0.0000 & -0.7071 & -0.6922 \\ \text { Taranaki } & 1 & 0.4765 & -0.3702 & -0.3714 \\ \text { Southland } & 1 & 0.3607 & -0.4521 & -0.4494 \\ \text { Manawatu } & 3 & 0.8396 & -0.8820 & -0.8588 \\ & & \mathrm{H} 0: \text { D1RPA does not Granger-cause D1HPA } & -0.7262 \\ \text { Whole sample } & 1 & 0.7030 & -0.6966 & 6.7628^{* *} \\ \text { Wellington } & 2 & 16.3979 & 7.1989 * * & -0.1870 \\ \text { Auckland } & 4 & 3.5565 & -0.1568 & -0.6558 \\ \text { Canterbury } & 1 & 0.0541 & -0.6689 & 0.6102 \\ \text { Nelson } & 1 & 1.9346 & 0.6608 & 1.0112 \\ \text { Hawke's Bay } & 1 & 2.5302 & 1.0820 & -0.6853 \\ \text { Otago } & 1 & 0.0103 & -0.6998 & -0.5047 \\ \text { Northland } & 1 & 0.2785 & -0.5102 & -0.3473 \\ \text { Waikato } & 1 & 0.5123 & -0.3449 & -0.3785 \\ \text { Taranaki } & 1 & 0.4659 & -0.37777 & -0.1393 \\ \text { 1Southland } & 1 & 0.8213 & -0.1264 & -0.1974 \\ \text { 7 Manawatu } & 1 & 0.7350 & -0.1874 & 1974\end{array}$

Notes: p-values computed using 1000 bootstrap replications. The presence of asterisks $(*, * *$ and $* * *)$ indicate statistically significance at the 10,5 and 1 percent confidence levels respectively using bootstrapped critical values (rather than asymptotic ones), which may be useful in the presence of cross-sectional dependence. Legend: * $\mathbf{p}<.05 ; * * \mathbf{p}<.01 ; * * * \mathbf{p}<.001$

Table 7 presents Dumitrescu and Hurlin (2012)'s Granger non-causality test abbreviated as the DH test. The study employs the DH test to examine the effect of HPA on RPA presented in Panel A and vice versa presented in Panel B. the optimal lags for almost regions are set equal to 1 for both panels A and B except some regions: for Panel A, the lag order of 1 is optimal for Wellington, Auckland, Manawatu; 2 for Nelson; 4 for Otago. While for Panel A, the optimal lags of 2 and 4 are for Welling and Auckland, respectively. The results of Table 7, Panel A show that for $1 \%$ increase in house price affordability (HPA), the rental price affordability (RPA) is increase by $6.77 \%, 25.6 \%, 10.9 \%, 10.2 \%$, and $7.04 \%$ for the whole country, Wellington, Auckland, Canterbury, and Hawke's Bay, respectively. The results are statistically significant at $1 \%, 5 \%$, and $10 \%$, respectively. For the effects of RPA on HPA presented in Table 7 Panel B, given 1\% increase in RPA, HPA is increased by $0.7 \%, 16.4 \%, 3.5 \%$, and $0.05 \%$ for New Zealand, Wellington, Auckland, and Canterbury, respectively. The result is statistically significant at 5\% for Wellington only. The results of the Dumitrescu and Hurlin test implies that Wellington, Auckland and Canterbury experience the most extreme relation and Granger non-causality effect between HPA and RPA compared with the other regions in New Zealand. 
Generalized-Least-Squares (GLS) Regression Results

Table 8: Generalized-Least-Squares (GLS) regressions Panel A: GLS regression of RPA

\begin{tabular}{lcccc}
\hline Dependent variable: $R P A_{i, t}$ & $(1)$ & $(2)$ & $(3)$ & $(4)$ \\
$R P A_{t}-1$ & $0.1558^{* * *}$ & 0.0193 & $0.1439^{* * *}$ & 0.0208 \\
& $(0.0234)$ & $(0.0266)$ & $(0.0248)$ & $(0.0275)$ \\
$R P A_{t+1}$ & $0.7338^{* * *}$ & $0.5899^{* * *}$ & $0.7303^{* * *}$ & $0.5912^{* * *}$ \\
$H P A_{i, t}$ & $(0.0232)$ & $(0.0268)$ & $(0.02456)$ & $(0.0282)$ \\
& $0.0175^{* * *}$ & $0.0170^{* * *}$ & $0.0154^{* * *}$ & $0.0138^{* * *}$ \\
$H P A_{i, t-1}$ & $(0.0006)$ & $(0.0006)$ & $(0.0009)$ & $(0.0009)$ \\
& $-0.0014^{* *}$ & -0.0002 & $-0.0015^{* *}$ & -0.00009 \\
$H P A_{i, t+1}$ & $(0.0004)$ & $(0.0005)$ & $(0.0005)$ & $(0.0005)$ \\
& $-0.0134^{* * *}$ & $-0.0117^{* * *}$ & $-0.0104^{* * *}$ & $-0.0095^{* * *}$ \\
Mortgage rate $e_{i, t}$ & $(0.0008)$ & $(0.0007)$ & $(0.0010)$ & $(0.0010)$ \\
& $-0.0041^{* * *}$ & $-0.004^{* * *}$ & $-0.0059^{*}$ & $-0.0087^{* *}$ \\
Mortgage rate $e_{i, t-1}$ & $(0.0011)$ & $(0.0012)$ & $(0.0027)$ & $(0.0026)$ \\
& 0.0008 & 0.0012 & 0.0519 & 00249 \\
Mortgage rate & $(0.0007)$ & $(0.0006)$ & $(0.0528)$ & $(0.0506)$ \\
& $0.0031^{* * *}+1$ & $0.0024^{* *}$ & $0.0105^{* * *}$ & $0.0078^{* * *}$ \\
Constant & $(0.0008)$ & $(0.0008)$ & $(0.0017)$ & $(0.0016)$ \\
& $0.0155^{* * *}$ & $0.1052^{* * *}$ & -0.0270 & -0.0084 \\
Number of observations & $(0.0038)$ & $(0.0104)$ & $(0.2757)$ & $(0.2656)$ \\
Prob $>X^{2}$ & 844 & 844 & 844 & 844 \\
Overall $R^{2}$ & 0.0000 & 0.0000 & 0.0000 & 0.0000 \\
Region Fixed-Effects & 0.9472 & 0.9524 & 0.9536 & 0.9580 \\
Time Fixed-Effects & No & Yes & No & Yes \\
\hline
\end{tabular}

${ }^{*} \mathrm{p}<.05 ; * * \mathrm{p}<.01 ; * * * \mathrm{p}<.001$

\begin{tabular}{lcccc}
\hline Panel B: GLS regression of HPA & & & & \\
\hline Dependent variable: $H P A_{i, t}$ & $(1)$ & $(2)$ & $(3)$ & $(4)$ \\
$H P A_{i, t-1}$ & 0.0130 & -0.0202 & 0.0067 & -0.0122 \\
& $(0.0186)$ & $(0.0195)$ & $(0.0170)$ & $(0.0177)$ \\
$H P A_{i, t+1}$ & $0.8438^{* * *}$ & $0.8067^{* * *}$ & $0.8389^{* * *}$ & $0.7692^{* * *}$ \\
$R P A_{t}$ & $(0.0190)$ & $(0.0200)$ & $(0.0214)$ & $(0.0238)$ \\
& $24.4747^{* * *}$ & $25.4933^{* * *}$ & $16.4450^{* * *}$ & $15.5891^{* * *}$ \\
$R P A_{t-1}$ & $(0.9772)$ & $(1.0144)$ & $(1.0244)$ & $(1.0826)$ \\
& -1.4590 & 0.9178 & 0.4401 & 0.7474 \\
$R P A_{t+1}$ & $(0.8975)$ & $(1.0304)$ & $(0.8310)$ & $(0.9253)$ \\
& $-17.9819^{* * *}$ & $-16.0607^{* * *}$ & $-11.9091^{* * *}$ & $-11.3023^{* * *}$ \\
Mortgage rate $_{i, t}$ & $(1.1243)$ & $(1.1824)$ & $(1.0994)$ & $(1.1181)$ \\
& $-0.2818^{* * *}$ & $-0.2662^{* * *}$ & $-0.7793 * * *$ & $-0.7908^{* * *}$ \\
Mortgage rate $_{i, t-1}$ & $(0.0409)$ & $(0.0406)$ & $(0.0861)$ & $(0.0855)$ \\
& 0.0180 & 0.0087 & -1.1877 & -1.0803 \\
Mortgage rate $_{i, t+1}$ & $(0.0270)$ & $(0.0268)$ & $(1.7288)$ & $(1.6988)$ \\
& $0.2645^{* * *}$ & $0.2616^{* * *}$ & $0.6361^{* * *}$ & $0.5710^{* * *}$ \\
Constant & $(0.0305)$ & $(0.0302)$ & $(0.0525)$ & $(0.0531)$ \\
& $-0.5248^{* * *}$ & $-1.9354^{*}$ & 6.4196 & 7.2126 \\
Number of observations & $(0.1454)$ & $(0.4228)$ & $(0.4770)$ & $(0.4180)$ \\
Prob $>X^{2}$ & 844 & 844 & 844 & 844 \\
Overall $R^{2}$ & 0.0000 & 0.0000 & 0.0000 & 0.0000 \\
Region Fixed-Effects & 0.9529 & 0.9545 & 0.9683 & 0.9699 \\
Time Fixed-Effects & No & Yes & No & Yes \\
\hline
\end{tabular}


Besides the tests of Westerlund 'error' (2007), Dumitrescu and Hurlin 'granger-causality' (2012) representing an existence of cointegration among HPA and RPA across the regions in New Zealand shown in Table 6 and 7, respectively; there is an extension of the study by detecting the lead-lag effect between RPA and HPA on each other and mortgage. The GLS regression models of RPA and HPA for the whole country are presented in Equation (3) and (4), respectively. In addition, the study examines the lead-lad effect of RPA and HPA specially for each region by employing the same models but using the pooled ordinary least squares (OLS) method. This OLS allows us to provide detailed within-region regression results for each region.

The results of GLS models are presented in Table 8 in which Panel A presents the GLS regression results of RPA and Panel B presents the GLS results of HPA. Where the subscripts of $i$ and $t$ denote region $i=1, \ldots \ldots, 11$; and time $t=1 \ldots \ldots, \mathrm{N}$. To detect the lead-lag effects among house price affordability, rental price affordability and mortgage rate; a lag is included at $t-1$ and lead values at $t+1$ into the empirical model. The results of Table 8 Panel $\mathrm{A}$ present a positive lead-lad effect of $R P A_{i, t-1}, R P A_{i, t+1}, H P A_{i, t}$, Mortgage $_{i, t-1}$ and Mortgage $_{i, t+1}$ on $R P A_{i, t}$. For $1 \%$ increase in those five variables predicts $0.15 \%, 0.73 \%$, $0.017 \%, 0.0008 \%$, and $0.0031 \%$ increase in $R P A_{i, t}$, respectively. The results are all statistically significant at $1 \%$ level presented in Column (1) when running the GLS model without region and time fixed-effects, except Mortgage $e_{i, t-1}$ that is insignificant. While there is a negative lead-lag effect of $H P A_{i, t-1}, H P A_{i, t+1}$, and Mortgage $e_{i, t}$. For instance, given $1 \%$ increase in those three variables decreases $R P A_{i, t}$ by $-0.0014 \%,-0.0134 \%$, and $-0.0041 \%$, respectively. The results stay consistent when including region fixed-effects (Column 2), time fixed-effects (Column 3), and both (Column 4) in Panel A Table 8. The results show strong lead-lag effects among variablesand are significant for all coefficients, except Mortgage $e_{i, t-1}$ with randomeffects presented in Column 1.

Capturing the similar objective, the GLS results of HPA presented in Table 8 Panel B show that there is a negative relation between $H P A_{i, t}, R P A_{i, t-1}, R P A_{i, t-1}, R P A_{i, t+1}$, and Mortgage $_{i, t}$. For $1 \%$ increase in those $H P A_{i, t+1}, R P A_{i, t-1}, R P A_{i, t-1}, R P A_{i, t+1}$ generates $1.45 \%,-17.98 \%$, and $-0.28 \%$ decrease in $H P A_{i, t}$. The results are all statistically significant at $1 \%$ level, except for $R P A_{i, t-1}$. While there is a positive effect of $H P A_{i, t-1}, H P A_{i, t+1}, R P A_{i, t}$, 
Mortgage $_{i, t-1}$, Mortgage Mot $+1_{1}$ on $H P A_{i, t}$. For example, for $1 \%$ increase in those four variables induces $0.013 \%, 0.8438 \%, 24.47 \%, 0.018 \%$, and $0.26 \%$ increase in $H P A_{i, t}$. The results are statistically significant at $1 \%$ level only for $H P A_{i, t+1}, R P A_{i, t}$, and Mortgage $e_{i, t+1}$. the empirical results imply the strongest lead-lad effects of $H P A_{i, t+1}, R P A_{i, t}, R P A_{i, t+1}$, Mortgage $_{i, t}$, and Mortgage $e_{i, t+1}$ on the current house price affordability. The results are all statistically significant at $1 \%$ level with an R-squared of $95 \%$ on average across Columns (1), (2), (3), and (4) with random-effects, region fixed-effects, time fixed-effects, and both, respectively. 
Table 9: Pooled Ordinary Least Squares (OLS) regression model by region

\begin{tabular}{|c|c|c|c|c|c|c|c|c|c|c|c|c|}
\hline $\begin{array}{c}\text { Dependent } \\
\text { variable: } R P A_{i, t}\end{array}$ & All regions & Auckland & Canterbury & $\begin{array}{c}\text { Hawke's } \\
\text { Bay }\end{array}$ & Manawatu & Nelson & $\begin{array}{c}\text { Northlan } \\
\text { d }\end{array}$ & Otago & Southland & Taranaki & Waikato & Wellington \\
\hline$R P A_{t-1}$ & $\begin{array}{c}0.1558^{* * * *} \\
(0.0234)\end{array}$ & $\begin{array}{l}-0.0562 \\
(0.0856)\end{array}$ & $\begin{array}{c}0.1303 \\
(0.0829)\end{array}$ & $\begin{array}{l}-0.0465 \\
(0.0877)\end{array}$ & $\begin{array}{c}0.0549 \\
(0.0864)\end{array}$ & $\begin{array}{l}-0.0157 \\
(0.0880)\end{array}$ & $\begin{array}{l}-0.1752 \\
(0.1073)\end{array}$ & $\begin{array}{l}-0.1983^{*} \\
(0.0827)\end{array}$ & $\begin{array}{l}-0.1356 \\
(0.0904)\end{array}$ & $\begin{array}{c}0.0684 \\
(0.1043)\end{array}$ & $\begin{array}{c}0.0184 \\
(0.0944)\end{array}$ & $\begin{array}{c}0.0211 \\
(0.1095)\end{array}$ \\
\hline$R P A_{t+1}$ & $\begin{array}{c}0.7338^{* * *} \\
(0.0282)\end{array}$ & $\begin{array}{c}0.6826^{* * *} \\
(0.0772)\end{array}$ & $\begin{array}{c}0.6313 * * * \\
(0.0852)\end{array}$ & $\begin{array}{c}0.5304 * * * \\
(0.1028)\end{array}$ & $\begin{array}{c}0.3831 * * * \\
(0.0916)\end{array}$ & $\begin{array}{c}0.5662 * * * \\
(0.0944)\end{array}$ & $\begin{array}{c}0.1952 \\
(0.1229)\end{array}$ & $\begin{array}{c}0.3011 * * \\
(0.1117)\end{array}$ & $\begin{array}{c}0.4931^{* * *} \\
(0.0975)\end{array}$ & $\begin{array}{c}0.4199 * * * \\
(0.1089)\end{array}$ & $\begin{array}{c}0.5927^{* * *} \\
(0.0994)\end{array}$ & $\begin{array}{l}(0.0824 \\
(0.110)\end{array}$ \\
\hline$H P A_{i, t}$ & $\begin{array}{c}0.0175 * * * \\
(0.0007)\end{array}$ & $\begin{array}{c}0.0140 * * * \\
(0.0013)\end{array}$ & $\begin{array}{c}0.0224 * * * \\
(0.0024\end{array}$ & $\begin{array}{c}0.0215^{* * *} \\
(0.0017)\end{array}$ & $\begin{array}{l}0.01194 * * * \\
(0.0030)\end{array}$ & $\begin{array}{c}0.0229 * * * \\
(0.0021)\end{array}$ & $\begin{array}{c}0.0155^{* * *} \\
(0.0018)\end{array}$ & $\begin{array}{c}0.0122 * * * \\
(0.0025)\end{array}$ & $\begin{array}{l}0.0079 * \\
(0.0030)\end{array}$ & $\begin{array}{c}0.0178^{* * * *} \\
(0.0030)\end{array}$ & $\begin{array}{c}0.0137 * * * \\
(0.0016)\end{array}$ & $\begin{array}{c}0.0239 * * * \\
(0.0028)\end{array}$ \\
\hline$H P A_{i, t-1}$ & $\begin{array}{c}-0.0013^{* *} \\
(0.0005)\end{array}$ & $\begin{array}{l}-0.0003 \\
(0.0007)\end{array}$ & $\begin{array}{l}-0.0013 \\
(0.0020)\end{array}$ & $\begin{array}{c}0.0016 \\
(0.0017)\end{array}$ & $\begin{array}{l}-0.0019 \\
(0.0012)\end{array}$ & $\begin{array}{c}0.0002 \\
(0.0017)\end{array}$ & $\begin{array}{c}0.0030 \\
(0.0025)\end{array}$ & $\begin{array}{l}0.0042^{*} \\
(0.0017)\end{array}$ & $\begin{array}{l}0.0047^{*} \\
.0019865\end{array}$ & $\begin{array}{l}-.000404 \\
.0021127\end{array}$ & $\begin{array}{c}0.0005 \\
(0.0016)\end{array}$ & $\begin{array}{l}-0.0007 \\
(0.0021)\end{array}$ \\
\hline$H P A_{i, t+1}$ & $\begin{array}{c}-0.0134 * * * \\
(0.0008)\end{array}$ & $\begin{array}{l}-0.012 * * * \\
(0.0016)\end{array}$ & $\begin{array}{c}-0.0165^{* * *} \\
(0.0028)\end{array}$ & $\begin{array}{l}-0.0139 \\
(0.0025)\end{array}$ & $\begin{array}{l}-0.0082 * \\
(0.0032)\end{array}$ & $\begin{array}{l}-0.0157 \\
(0.0027)\end{array}$ & $\begin{array}{c}0.0019 \\
(0.0025)\end{array}$ & $\begin{array}{l}-0.0036 \\
(0.0028\end{array}$ & $\begin{array}{c}0.0011 \\
(0.0033)\end{array}$ & $\begin{array}{l}-0.0086^{*} \\
(0.0034)\end{array}$ & $\begin{array}{c}-0.0076^{* * *} \\
(0.0016)\end{array}$ & $\begin{array}{c}-0.0130 * * * \\
(0.0030)\end{array}$ \\
\hline Mortgage rate $_{i, t}$ & $\begin{array}{c}-0.0041 * * * \\
(0.0011)\end{array}$ & $\begin{array}{c}-0.0106 * * \\
(0.0035)\end{array}$ & $\begin{array}{c}-0.0086^{*} \\
(0.0041)\end{array}$ & $\begin{array}{c}0.0020 \\
(0.0025)\end{array}$ & $\begin{array}{c}0.0014 \\
(0.0020)\end{array}$ & $\begin{array}{c}-0.0058 \\
(0.0032)\end{array}$ & $\begin{array}{c}-0.0028 \\
(0.0024)\end{array}$ & $\begin{array}{c}-0.01107 * \\
(0.0041)\end{array}$ & $\begin{array}{c}-0.0013 \\
(0.0029)\end{array}$ & $\begin{array}{l}-0.0020 \\
(0.0032)\end{array}$ & $\begin{array}{l}-0.0033 \\
(0.0020)\end{array}$ & $\begin{array}{l}(0.0053 \\
(0.0046)\end{array}$ \\
\hline Mortgage rate $_{i, t-}$ & $\begin{array}{c}0.0007 \\
(0.0007)\end{array}$ & $\begin{array}{l}0.0052 * \\
(0.0025)\end{array}$ & $\begin{array}{c}0.0015 \\
(0.0024)\end{array}$ & $\begin{array}{l}-0.0026 \\
(0.0015)\end{array}$ & $\begin{array}{c}0.0005 \\
(0.0013)\end{array}$ & $\begin{array}{l}0.0039 * \\
(0.0019)\end{array}$ & $\begin{array}{c}0.0011 \\
(0.0017)\end{array}$ & $\begin{array}{c}-0.0013 \\
(0.0029)\end{array}$ & $\begin{array}{c}0.0013 \\
(0.0017)\end{array}$ & $\begin{array}{c}0.0026 \\
(0.0022)\end{array}$ & $\begin{array}{c}0.00179 \\
(0.0012)\end{array}$ & $\begin{array}{l}-0.0017 \\
(0.0026)\end{array}$ \\
\hline Mortgage rate $_{i, t+}$ & $\begin{array}{c}0.0031^{* * *} \\
(0.0008)\end{array}$ & $\begin{array}{l}0.0054^{*} \\
(0.0024)\end{array}$ & $\begin{array}{c}0.0051 \\
(0.0034)\end{array}$ & $\begin{array}{c}0.0003 \\
(0.0019)\end{array}$ & $\begin{array}{c}-0.0006 \\
(0.0016)\end{array}$ & $\begin{array}{c}0.0026 \\
(0.0026)\end{array}$ & $\begin{array}{c}0.0002 \\
(0.0018)\end{array}$ & $\begin{array}{c}0.0044 \\
(0.0034)\end{array}$ & $\begin{array}{c}-0.0001 \\
(0.0023)\end{array}$ & $\begin{array}{c}0.0001 \\
(0.0024)\end{array}$ & $\begin{array}{c}0.0011 \\
(0.0017)\end{array}$ & $\begin{array}{l}-0.0053 \\
(0.0037)\end{array}$ \\
\hline Constant & $\begin{array}{c}0.01549 * * * \\
(0.0038)\end{array}$ & $\begin{array}{c}0.1228^{* *} \\
(0.0399)\end{array}$ & $\begin{array}{c}0.0478 \\
(0.0245)\end{array}$ & $\begin{array}{c}0.0949 * * * \\
(0.0245)\end{array}$ & $\begin{array}{c}0.1170^{* * *} \\
(0.0261)\end{array}$ & $\begin{array}{c}0.0801 * * \\
(0.0244)\end{array}$ & $\begin{array}{c}0.1534 * * * \\
(0.0243)\end{array}$ & $\begin{array}{c}0.2367 * * * \\
(0.0399)\end{array}$ & $\begin{array}{c}0.0802 * * * \\
(0.0196)\end{array}$ & $\begin{array}{c}0.0764 * * \\
(0.0262)\end{array}$ & $\begin{array}{l}0.0667 * \\
(0.0266)\end{array}$ & $\begin{array}{c}0.2138 * * * \\
(0.0365)\end{array}$ \\
\hline Observations (N) & 844 & 75 & 77 & 77 & 77 & 77 & 77 & 77 & 76 & 77 & 77 & 77 \\
\hline Prob $>$ F & 0.0000 & 0.0000 & 0.0000 & 0.0000 & 0.0000 & 0.0000 & 0.0000 & 0.0000 & 0.0000 & 0.0000 & 0.0000 & 0.0000 \\
\hline R-squared $\left(R^{2}\right)$ & 0.9472 & 0.8556 & 0.8877 & 0.8825 & 0.5459 & 0.9039 & 0.9180 & 0.7864 & 0.8533 & 0.7366 & 0.9269 & 0.6770 \\
\hline
\end{tabular}




\begin{tabular}{|c|c|c|c|c|c|c|c|c|c|c|c|c|}
\hline \multicolumn{13}{|c|}{ Panel B: Pooled OLS regressions of HPA by region } \\
\hline $\begin{array}{c}\text { Dependent } \\
\text { variable: } H P A_{i, t}\end{array}$ & All regions & Auckland & Canterbury & $\begin{array}{c}\text { Hawke's } \\
\text { Bay }\end{array}$ & Manawatu & Nelson & Northland & Otago & Southland & Taranaki & Waikato & Wellington \\
\hline$H P A_{i, t-1}$ & $\begin{array}{c}0.0130 \\
(0.0186)\end{array}$ & $\begin{array}{l}-0.0312 \\
(0.0436)\end{array}$ & $\begin{array}{l}0.01341 \\
(0.0667)\end{array}$ & $\begin{array}{l}-0.0584 \\
(0.0669)\end{array}$ & $\begin{array}{c}0.0213 \\
(0.0447)\end{array}$ & $\begin{array}{l}-0.0328 \\
(0.0610)\end{array}$ & $\begin{array}{l}-0.0053 \\
(0.1174)\end{array}$ & $\begin{array}{l}-0.0960 \\
(0.0753)\end{array}$ & $\begin{array}{c}0.0197 \\
(0.0785)\end{array}$ & $\begin{array}{c}0.0009 \\
(0.0684)\end{array}$ & $\begin{array}{l}-0.0867 \\
(0.0844)\end{array}$ & $\begin{array}{c}0.0443 \\
(0.0631)\end{array}$ \\
\hline$H P A_{i, t+1}$ & $\begin{array}{c}0.8438^{* * *} \\
(0.0190)\end{array}$ & $\begin{array}{c}0.9269 * * * \\
(0.0493)\end{array}$ & $\begin{array}{c}0.7714 * * * \\
(0.0653)\end{array}$ & $\begin{array}{c}0.7044 * * * \\
.0822244\end{array}$ & $\begin{array}{c}0.9128 * * * \\
(0.0465)\end{array}$ & $\begin{array}{c}0.7575^{* * * *} \\
(0.0688)\end{array}$ & $\begin{array}{c}0.0355 \\
(0.1150)\end{array}$ & $\begin{array}{c}0.6868 * * * \\
(0.0829)\end{array}$ & $\begin{array}{c}0.7875^{* * *} \\
(0.0840)\end{array}$ & $\begin{array}{c}0.7274 * * * \\
(0.0730)\end{array}$ & $\begin{array}{c}0.5109 * * * \\
(0.0766)\end{array}$ & $\begin{array}{c}0.6451 * * * \\
(0.0643)\end{array}$ \\
\hline$R P A_{t}$ & $\begin{array}{c}24.4747 * * * \\
(0.9772)\end{array}$ & $\begin{array}{c}45.3208 * * * \\
(4.2210)\end{array}$ & $\begin{array}{c}24.3847 * * * \\
(2.6977)\end{array}$ & $\begin{array}{c}31.7772 * * * \\
(2.6204)\end{array}$ & $\begin{array}{c}15.3902 * * * \\
(3.9336)\end{array}$ & $\begin{array}{c}27.7937 * * * \\
(2.5353)\end{array}$ & $\begin{array}{c}32.6073 * * * \\
(3.9143)\end{array}$ & $\begin{array}{c}20.6050 * * * \\
(4.3058)\end{array}$ & $\begin{array}{l}11.4859^{*} \\
(4.4282)\end{array}$ & $\begin{array}{c}18.7149 * * * \\
(3.2071)\end{array}$ & $\begin{array}{c}36.7992 * * * \\
(4.4139)\end{array}$ & $\begin{array}{c}21.0026^{* * * *} \\
(2.5282)\end{array}$ \\
\hline$R P A_{t-1}$ & $\begin{array}{l}-1.4590 \\
(0.8975)\end{array}$ & $\begin{array}{c}7.0970 \\
(4.8030)\end{array}$ & $\begin{array}{l}-1.5467 \\
(2.7810)\end{array}$ & $\begin{array}{c}0.5783 \\
(3.3771)\end{array}$ & $\begin{array}{l}-1.5098 \\
(3.1091)\end{array}$ & $\begin{array}{c}1.8998 \\
(3.0542)\end{array}$ & $\begin{array}{c}2.7623 \\
(5.0098)\end{array}$ & $\begin{array}{c}1.7500 \\
(3.5305)\end{array}$ & $\begin{array}{l}-1.8981 \\
(3.489)\end{array}$ & $\begin{array}{c}0.4159 \\
(3.3901)\end{array}$ & $\begin{array}{c}3.9748 \\
(4.8667)\end{array}$ & $\begin{array}{l}-1.5850 \\
(3.2387)\end{array}$ \\
\hline$R P A_{t+1}$ & $\begin{array}{c}-17.9819 * * * \\
(1.1243)\end{array}$ & $\begin{array}{c}-40.2936^{* *} \\
(4.1810)\end{array}$ & $\begin{array}{c}-15.4161 * * * \\
(3.2877)\end{array}$ & $\begin{array}{c}-16.4242^{* * * *} \\
(4.2159)\end{array}$ & $\begin{array}{l}-7.7968^{*} \\
(3.5653)\end{array}$ & $\begin{array}{c}-14.99101^{* * *} \\
3.632247\end{array}$ & $\begin{array}{c}8.9886 \\
(5.6405)\end{array}$ & $\begin{array}{l}-3.4904 \\
(4.8090)\end{array}$ & $\begin{array}{l}-2.2815 \\
(4.3507)\end{array}$ & $\begin{array}{l}-5.6075 \\
(3.8367)\end{array}$ & $\begin{array}{l}-8.0457 \\
(6.2752)\end{array}$ & $\begin{array}{c}0.7255 \\
(3.2681)\end{array}$ \\
\hline Mortgage rate $_{i, t}$ & $\begin{array}{c}-0.2818^{* * *} \\
(0.0409)\end{array}$ & $\begin{array}{c}0.1678 \\
(0.2140)\end{array}$ & $\begin{array}{l}-0.2376 \\
(0.1395)\end{array}$ & $\begin{array}{c}-0.3077 * * \\
(0.0910)\end{array}$ & $\begin{array}{l}-0.1440^{*} \\
(0.0713)\end{array}$ & $\begin{array}{l}-0.1267 \\
(0.1129)\end{array}$ & $\begin{array}{l}-0.0524 \\
(0.1140)\end{array}$ & $\begin{array}{c}0.0268 \\
(0.1794)\end{array}$ & $\begin{array}{l}-0.0919 \\
(0.1099)\end{array}$ & $\begin{array}{l}-0.2325^{*} \\
(0.1013)\end{array}$ & $\begin{array}{l}-0.2605^{*} \\
(0.1052)\end{array}$ & $\begin{array}{c}-0.5844 * * * \\
(0.1180)\end{array}$ \\
\hline Mortgage rate $_{i, t-1}$ & $\begin{array}{c}0.0180 \\
(0.0270)\end{array}$ & $\begin{array}{c}-0.2667 \\
(0.14373)\end{array}$ & $\begin{array}{c}0.0026 \\
(0.0807)\end{array}$ & $\begin{array}{l}0.1361 * \\
(0.0592)\end{array}$ & $\begin{array}{c}0.0228 \\
(0.0486)\end{array}$ & $\begin{array}{l}-0.0947 \\
(0.0671)\end{array}$ & $\begin{array}{l}-0.0050 \\
(0.0795)\end{array}$ & $\begin{array}{c}0.0089 \\
(0.1220)\end{array}$ & $\begin{array}{c}0.0670 \\
(0.0638)\end{array}$ & $\begin{array}{l}-0.0402 \\
(0.0725)\end{array}$ & $\begin{array}{l}-0.0228 \\
(0.0619)\end{array}$ & $\begin{array}{c}0.0902 \\
(0.0767)\end{array}$ \\
\hline Mortgage rate $_{i, t+1}$ & $\begin{array}{c}0.2645 * * * \\
(0.0305)\end{array}$ & $\begin{array}{c}0.0703 \\
(0.1393)\end{array}$ & $\begin{array}{l}0.2603 * \\
(0.1108)\end{array}$ & $\begin{array}{l}0.1914^{*} \\
(0.0718)\end{array}$ & $\begin{array}{l}0.1055^{*} \\
(0.0558)\end{array}$ & $\begin{array}{l}0.1956^{*} \\
(0.0876)\end{array}$ & $\begin{array}{c}0.1101 \\
(0.0818)\end{array}$ & $\begin{array}{c}0.1429 \\
(0.1352)\end{array}$ & $\begin{array}{c}0.0457 \\
(0.0887)\end{array}$ & $\begin{array}{c}0.2534 * * \\
(0.0728)\end{array}$ & $\begin{array}{c}0.3136 * * * \\
(0.0799)\end{array}$ & $\begin{array}{c}0.5338 * * * \\
(0.0908)\end{array}$ \\
\hline Constant & $\begin{array}{c}-0.5248^{* * *} \\
(0.1454)\end{array}$ & $\begin{array}{l}-3.4473 \\
(2.3923)\end{array}$ & $\begin{array}{l}-0.7352 \\
(0.8262)\end{array}$ & $\begin{array}{l}-2.5771 * \\
(0.9951)\end{array}$ & $\begin{array}{l}-1.0605 \\
(1.0605)\end{array}$ & $\begin{array}{c}-2.3842 * * \\
(0.8652)\end{array}$ & $\begin{array}{c}-6.5609 * * * \\
(1.1574)\end{array}$ & $\begin{array}{c}-4.0661 \\
(1.9591)^{*}\end{array}$ & $\begin{array}{l}-0.9567 \\
(0.8268)\end{array}$ & $\begin{array}{l}-1.8345^{*} \\
(0.8727)\end{array}$ & $\begin{array}{c}-5.5367 * * * \\
(1.2727)\end{array}$ & $\begin{array}{c}-4.2645^{* *} \\
(1.2198)\end{array}$ \\
\hline Observations $(\mathrm{N})$ & 844 & 75 & 77 & 77 & 77 & 77 & 77 & 77 & 76 & 77 & 77 & 77 \\
\hline Prob $>X^{2}$ & 0.0000 & 0.0000 & 0.0000 & 0.0000 & 0.0000 & 0.0000 & 0.0000 & 0.0000 & 0.0000 & 0.0000 & 0.0000 & 0.0000 \\
\hline $\mathrm{R}$-squared $\left(R^{2}\right)$ & 0.9529 & 0.9646 & 0.9179 & 0.9314 & 0.9096 & 0.9544 & 0.9099 & 0.8366 & 0.9089 & 0.8855 & 0.9410 & 0.8947 \\
\hline
\end{tabular}

Beside the established lead-lag effects presented in Table 8 with the GLS model, the study explores further the lead-lad volatility among variables for each of 11 regions in New Zealand using the pooled (OLS) method shown in Table 9. The results show a perfect consistency for the whole region compared to the GLS approach and are statistically significant at $1 \%$ level. The signs of the lead-lag effects are consistent across regions with some exceptional cases. For example, for Table 9 Panel A, while the negative lead-lag effects of $H P A_{i, t}-1, H P A_{i, t}+1$, and Mortgage rate $_{i, t}$ on $R P A_{i, t}$ are hold across almost the regions, the results show a reverse effects in Nelson, Northland, Otago, Southland and Waikato for $H P A_{i, t-1}$; Northland and Southland for $H P A_{i, t-1}$; Hawkes' Bay, Manawatu, and Wellington for Mortgage $e_{i, t}$. However, the 
results are almost insignificant for the reverse lead-lag effects in those exceptional regions. The results are slightly significant at a $10 \%$ level for $H P A_{i, t-1}$ in Otago an Southland. For RPA presented in Panel B, the results are highly consistent for both the whole country and within each region; however, the inverse lead-lag effects appear in some regions in New Zealand. For instance, the established negative effects of $R P A_{i, t+1}$ on $H P A_{i, t}$ are hold across the regions, while the reverse effects appear in Northland and Wellington. 


\section{Discussion of Results}

Application of the Levin-Lin-Chu test above confirms that the series are stationary after first differencing, and this enables the use of the Westerlund and Persyn (2007) cointegration test which assumes that all unit roots should be integrated of order one. The Westerlund and Persyn panel cointegration approach is applied to identify whether their stationary linear combination of the two variables and essentially test whether error-correction is present for individual regions and for the panel as a whole. To ensure that the cross-sectional units are not strongly affected by common factors, the study bootstrapped robust critical values for the test statistics.

Table 10 reveals these estimates along with their bootstrapped robust critical values, the results of all the models confirm the presence of a strong cointegration relationship between $R P A$ and $H P A$ and rejects the null hypothesis of no cointegration at the 1 percent significance level. Hence, there is significant equilibrium relationship between the variables over the long term. The study re-estimated the same model for each of the eleven regions of New Zealand, and confirms that the same result holds for each region individually. The question then is whether one of the variables (Granger-) causes the other over the long term.

Table 10: Westerlund error correction model panel cointegration tests

\begin{tabular}{|c|c|c|c|c|c|}
\hline & Statistics & Value & Z-value & P-value & Robust P-value \\
\hline \multirow{4}{*}{$\begin{array}{l}\text { Whole } \\
\text { sample }\end{array}$} & $\mathrm{Gt}$ & -8.1181 & -23.408 & 0.000 & 0.000 \\
\hline & $\mathrm{Ga}$ & -112.117 & -63.957 & 0.000 & 0.000 \\
\hline & $\mathrm{Pt}$ & -28.075 & -23.409 & 0.000 & 0.000 \\
\hline & $\mathrm{Pa}$ & -119.214 & -85.901 & 0.000 & 0.000 \\
\hline \multirow{4}{*}{ Auckland } & $\mathrm{Gt}$ & -6.024 & -4.747 & 0.000 & 0.000 \\
\hline & $\mathrm{Ga}$ & -54.742 & -8.744 & 0.000 & 0.000 \\
\hline & $\mathrm{Pt}$ & -6.042 & -4.621 & 0.000 & 0.000 \\
\hline & $\mathrm{Pa}$ & -54.7424 & -11.378 & 0.000 & 0.000 \\
\hline \multirow{4}{*}{ Northland } & $\mathrm{Gt}$ & -6.994 & -5.806 & 0.000 & 0.000 \\
\hline & $\mathrm{Ga}$ & -89.105 & -15.056 & 0.000 & 0.000 \\
\hline & $\mathrm{Pt}$ & -6.994 & -5.578 & 0.000 & 0.000 \\
\hline & $\mathrm{Pa}$ & -89.105 & -19.118 & 0.000 & 0.000 \\
\hline \multirow{4}{*}{ Otago } & Gt & -9.069 & -8.116 & 0.000 & 0.000 \\
\hline & $\mathrm{Ga}$ & -129.458 & -622.469 & 0.000 & 0.000 \\
\hline & $\mathrm{Pt}$ & -9.069 & -7.666 & 0.000 & 0.000 \\
\hline & $\mathrm{Pa}$ & -129.458 & -28.208 & 0.000 & 0.000 \\
\hline \multirow{4}{*}{ Waikato } & Gt & -8.534 & -7.521 & 0.000 & 0.000 \\
\hline & $\mathrm{Ga}$ & -121.852 & -21.072 & 0.000 & 0.000 \\
\hline & $\mathrm{Pt}$ & -8.534 & -7.127 & 0.000 & 0.000 \\
\hline & $\mathrm{Pa}$ & -121.852 & -26.494 & 0.000 & 0.000 \\
\hline
\end{tabular}




\begin{tabular}{|c|c|c|c|c|c|}
\hline & $\mathrm{Gt}$ & -7.532 & -6.405 & 0.000 & 0.000 \\
\hline Hawke's & $\mathrm{Ga}$ & -99.053 & -16.884 & 0.000 & 0.000 \\
\hline \multirow[t]{2}{*}{ Bay } & $\mathrm{Pt}$ & -7.532 & -6.119 & 0.000 & 0.000 \\
\hline & $\mathrm{Pa}$ & -99.053 & -21.358 & 0.000 & 0.000 \\
\hline \multirow{4}{*}{ Taranaki } & $\mathrm{Gt}$ & -8.082 & -7.017 & 0.000 & 0.000 \\
\hline & $\mathrm{Ga}$ & -84.573 & -14.224 & 0.000 & 0.000 \\
\hline & $\mathrm{Pt}$ & -8.082 & -6.673 & 0.000 & 0.000 \\
\hline & $\mathrm{Pa}$ & -84.573 & -18.097 & 0.000 & 0.000 \\
\hline \multirow{4}{*}{ Manuwatu } & $\mathrm{Gt}$ & -8.029 & -6.959 & 0.000 & 0.000 \\
\hline & $\mathrm{Ga}$ & -127.378 & -22.087 & 0.000 & 0.000 \\
\hline & $\mathrm{Pt}$ & -8.029 & -6.620 & 0.000 & 0.000 \\
\hline & $\mathrm{Pa}$ & -127.378 & -27.739 & 0.000 & 0.000 \\
\hline \multirow{4}{*}{ Wellington } & $\mathrm{Gt}$ & -10.964 & -10.225 & 0.000 & 0.000 \\
\hline & $\mathrm{Ga}$ & -228.545 & -40.672 & 0.000 & 0.000 \\
\hline & $\mathrm{Pt}$ & -10.964 & -9.571 & 0.000 & 0.000 \\
\hline & $\mathrm{Pa}$ & -228.545 & -50.527 & 0.000 & 0.000 \\
\hline \multirow{4}{*}{ Nelson } & $\mathrm{Gt}$ & -9.497 & -8.593 & 0.000 & 0.000 \\
\hline & $\mathrm{Ga}$ & -113.676 & -19.570 & 0.000 & 0.000 \\
\hline & $\mathrm{Pt}$ & -9.497 & -8.096 & 0.000 & 0.000 \\
\hline & $\mathrm{Pa}$ & -113.676 & -24.653 & 0.000 & 0.000 \\
\hline \multirow{4}{*}{ Canterbury } & $\mathrm{Gt}$ & -6.712 & -5.493 & 0.000 & 0.000 \\
\hline & $\mathrm{Ga}$ & -90.083 & -15.236 & 0.000 & 0.000 \\
\hline & $\mathrm{Pt}$ & -6.712 & -5.295 & 0.000 & 0.000 \\
\hline & $\mathrm{Pa}$ & -90.083 & -19.339 & 0.000 & 0.000 \\
\hline \multirow{4}{*}{ Southland } & $\mathrm{Gt}$ & -7.846 & -6.754 & 0.000 & 0.000 \\
\hline & $\mathrm{Ga}$ & -94.819 & -16.106 & 0.000 & 0.000 \\
\hline & $\mathrm{Pt}$ & -7.846 & -6.435 & 0.000 & 0.000 \\
\hline & $\mathrm{Pa}$ & -94.819 & -20.405 & 0.000 & 0.000 \\
\hline
\end{tabular}

Notes: Models contain 1 lag and 1 lead and are estimated with 100 bootstrap iterations. This used the Alkaline Information Criterion to determine the lag length for each series using the Bartlett kernel window width.

\section{Dumitrescu and Hurlin (2012) Granger non-causality tests}

Application of Dumitrescu and Hurlin's (2012) Granger non-causality panel tests reveal that the statistically optimal lag is one lag in both instances. The results suggest that rental price affordability does not Granger-cause house price affordability, but the study can reject the reverse direction of causality at the 1 percent level, and hence house price affordability does Granger-cause rental price affordability.

Table 11: Dumitrescu and Hurlin's (2012) Granger non-causality test

\begin{tabular}{lcccc}
\hline & Lag order & W-bar & Z-bar & Z-bar tilde \\
\hline \multicolumn{4}{c}{ H0: D1HPA does } & not Granger-cause D1RPA \\
Whole sample & 1 & 6.5001 & $12.8989^{* * *}$ & $12.1577^{* * *}$ \\
Wellington & 3 & 25.6701 & $9.2550^{* * *}$ & $8.5445^{* * *}$ \\
Auckland & 3 & 12.7564 & $3.9830^{* *}$ & $3.6553^{* *}$ \\
Canterbury & 1 & 6.0609 & $3.5786^{* *}$ & $3.3714^{* *}$ \\
Nelson & 2 & 8.0457 & $3.0229^{* *}$ & $2.8051^{* *}$ \\
Hawke's Bay & 1 & 4.5350 & $2.4996^{* *}$ & $2.3486^{* *}$ \\
Otago & 4 & 7.2076 & 1.1341 & 0.9925
\end{tabular}




$\begin{array}{lllll}\text { Northland } & 1 & 1.9360 & 0.6618 & 0.6067 \\ \text { Waikato } & 1 & 0.8533 & -0.1037 & -0.1189 \\ \text { Taranaki } & 1 & 0.8266 & -0.1226 & -0.1369 \\ \text { Southland } & 1 & 0.4136 & -0.4147 & -0.4137 \\ \text { Manawatu } & 3 & 1.0520 & -0.7953 & -0.7760\end{array}$

\begin{tabular}{llccc} 
Whole sample & 1 & 0.7603 & -0.5622 & -0.6013 \\
Wellington & 2 & 31.6020 & $14.8010^{* * *}$ & $13.8529^{* * *}$ \\
Auckland & 4 & 3.2611 & -0.2613 & -0.2856 \\
Canterbury & 1 & 1.2686 & 0.1900 & 0.1594 \\
Nelson & 1 & 1.8526 & 0.6029 & 0.5508 \\
Hawke's Bay & 1 & 2.1172 & 0.7900 & 0.7281 \\
3 Otago & 1 & 0.1254 & -0.6184 & -0.6068 \\
2 Northland & 1 & 0.0197 & -0.6931 & -0.6776 \\
4 Waikato & 1 & 0.0007 & -0.7066 & -0.6904 \\
6 Taranaki & 1 & 0.3570 & -0.4547 & -0.4516 \\
1 Southland & 1 & 1.4476 & 0.3165 & 0.2794 \\
7 Manawatu & 1 & 0.0801 & -0.6505 & -0.6372 \\
\hline
\end{tabular}

Notes: p-values computed using 1000 bootstrap replications. The presence of asterisks $(*, * *$ and $* * *)$ indicate statistically significance at the 10,5 and 1 percent confidence levels respectively using bootstrapped critical values (rather than asymptotic ones), which may be useful in the presence of cross-sectional dependence.

Legend: * $\mathbf{p}<.05 ; * * \mathbf{p}<.01 ; * * * \mathbf{p}<.001$

Application of Dumitrescu and Hurlin's (2012) Granger non-causality test results to individual regions generate the results presented in Table 11. These results suggest that house price affordability Granger-causes rental price affordability in Wellington, Auckland, Canterbury, Nelson and Hawke's Bay but the evidence for the reverse Granger-causality, from rental price affordability to house price affordability, is only present for Wellington with a lag of half a year.

Several interesting points are generated from these tests applied to individual regions. First, Wellington, the capital city and political centre of New Zealand, has a bidirectional causality, whereby house price affordability Granger-causes rental price affordability after 9 months and rental price affordability Granger-causes house price affordability after 6 months. Given the longer time lag from house price affordability to rental affordability, if the government wishes to control house prices then they should look at controlling the rate of increase of rental values.

Second, Auckland is so populous and with many neighbourhoods that there is not statistical evidence of a relationship from rental price affordability to house price affordability. This is not surprising as it is a major world city with high amounts of rental properties in the housing market. However, there is a statistically significant relationship from house price affordability to rental price affordability. One interpretation here is that higher house price 
values incentives investors to purchase a property to rent out in order to extract a long run return.

Third, there is evidence that house price affordability Granger-causes rental price affordability after one or two quarters in Canterbury, Hawke's Bay and Nelson. One inference for this causality is that these regions have relatively limited (less elastic) supply of rental housing, and thus open to following house price fluctuations.

\section{Conclusion}

The study finds significant existence of cointegration and unidirectional causality effects between HPA and RPA across 11 regions in New Zealand. Auckland, Wellington and Canterbury are the three regions in which the results detect the most extreme effects among HPA and RPA compared to other places in the country. With the demonstrated cointegration, the study also presents crucial lead-lad effects among house price affordability and rental price affordability across all the regions and the whole country.

Application of Granger non-causality panel tests reveal that the statistically optimal lag length is equal to one quarter with house price affordability Granger-causing rental price affordability over the period 2000q1 to 2019q2. Application of Granger non-causality test results to individual regions suggest that house price affordability Granger-causes rental price affordability in Wellington, Auckland, Canterbury, Nelson and Hawke's Bay and that rental price affordability Granger-causes house price affordability in Wellington only. Besides the presence of cointegration in New Zealand's housing markets across the regions, the regression results show the insightful lead-lag correlations among house price affordability and rental price affordability in New Zealand as the whole and the correlations are volatized across the regions in the sample.

The results show some need for policy to consider rental affordability, particularly if there is a longer time lag from house price affordability to rental affordability. Plus the study raises the need to explore further reasons for such HPA and RPA affordability relationship lags-leads. As presented in the literature, determinants beyond relative tenure affordability can also contribute. Contributions such as the supply-demand of stock, investment-finance, and the policy tools in place to shape affordability in the housing market. The overall results of the study show profound interactions among rental 
and housing markets in New Zealand; for example, through the OLS results, given 1\% increase in rental price affordability and housing price affordability in the last quarter at $t-1$, the study predicts the future rental price affordability to be increased by $15.58 \%$ and only decreased by $-0.013 \%$ in house price affordability in the next quarter at $t+1$ for the whole country over the last 20 years on average. More importantly, those leadlag correlations among housing price affordability, rental price affordability and mortgage rate are consistent but not fixed for all the regions in New Zealand.

Given the empirical findings, the study is one of the first research works in New Zealand's housing and rental markets showing intensive volatilities in the correlations among different regions in the country. Given the complexity, the findings are expected to provide a reference for both policy makers, analysts, academic institutions, governments in terms of modelling and forecasting housing prices, rental prices, and mortgage rates. Further modelling and forecasting can draw on this work for their estimated affordability measures specifically in New Zealand and at a global scale. The central goals of this research are implemented to be specific for New Zealand and within its regions. Hence, future studies are needed to further detect and compare those cointegration and time-varying effects among difference regions in New Zealand through applying other empirical settings and techniques for a more insightful comparison. Also, a spill over effect is also an important angle that can explore further across different housing markets. 


\section{References}

Archer, M., Bhaskar, R., Collier, A., Lawson, T., \& Norrie, A. (Eds.). (2013). Critical realism: Essential readings. Routledge.

Bhaskar, R. (2016). Enlightened common sense: The philosophy of critical realism. Routledge.

Baker, E., Bentley, R., Lester, L. and Beer, A. (2016). Housing affordability and residential mobility as drivers of locational inequality. Applied Geography, 72, 65-75.

Beer, A., Kearins, B. and Pieters, H. (2007). Housing affordability and planning in Australia: the challenge of policy under neo-liberalism. Housing Studies, 22(1), 11-24.

Ben-Shahar, D., Gabriel, S., \& Golan, R. (2019). Housing affordability and inequality: A consumption-adjusted approach. Journal of Housing Economics, 45, 101567.

Bramley, G. (1994). An affordability crisis in British housing: dimensions, causes and policy impact. Housing Studies, 9(1), 103-124

Bogdon, A. S., and Can, A. (1997). Indicators of local housing affordability: Comparative and spatial approaches. Real Estate Economics, 25(1), 43-80.

Collinson, R. (2011). Rental Housing Affordability Dynamics, 1990-2009. Cityscape, 71103.

Dong, H. (2018). The impact of income inequality on rental affordability: An empirical study in large American metropolitan areas. Urban Studies, 55(10), 2106-2122.

Dumitrescu, E.-I., \& Hurlin, C. (2012). Testing for Granger non-causality in heterogeneous panels. Economic Modelling, 29(4), 1450-1460. https://doi.org/10.1016/j.econmod.2012.02.014

Dykes, P. (2018). The quasi-market approach: the answer for social housing in New Zealand? Policy Quarterly, 12(2).

Eaqub, S. and Eaqub, S. (2015) Generation Rent: rethinking New Zealand's priorities, BWB Texts: Wellington.

Fisher, L. M., Pollakowski, H. O., \& Zabel, J. (2009). Amenity-based housing affordability indexes. Real Estate Economics, 37(4), 705-746.

Foye, C., Clapham, D. and Gabrieli, T. (2017) Home-ownership as a social norm and positional good: subjective wellbeing evidence from panel data, Urban Studies, 55(6), 1290-1312

Fraser, P., Hoesli, M. and McAlevey, L. (2008). House prices and bubbles in New Zealand. The Journal of Real Estate Finance and Economics, 37(1), 71-91.

Gan, Q. and Hill, R. J. (2009). Measuring housing affordability: Looking beyond the median. Journal of Housing Economics, 18(2), 115-125. 
Glaeser, E. and Gyourko, J. (2003) The impact of building restrictions on housing affordability. Economic Policy Review, 9(2), 21-39.

Gray, D. (2012) District House Price Movements in England and Wales 1997-2007: An Exploratory Spatial Data Analysis Approach, Urban Studies, 49(7), pp. 1411-1434.

Gyourko, J., and Linneman, P. (1993). Affordability of the American dream: An examination of the last 30 years, Journal of Housing Research, 4(1), 39.

Haffner, M. E., and Boumeester, H. J. (2010). The affordability of housing in the Netherlands: An increasing income gap between renting and owning? Housing Studies, 25(6), 799-820.

Hargreaves, B. (2003). Determinants of housing tenure choice in New Zealand. Pacific Rim Property Research Journal, 9(3), 203-223.

Ho, M. H., \& Chiu, R. L. (2002). Impact of accessibility on housing expenditure and affordability in Hong Kong's private rental sector. Journal of Housing and the Built Environment, 17(4), 363-383.

Hoolachan, J., McKee, K., Moore, T., \& Soaita, A. M. (2017). 'Generation rent'and the ability to 'settle down': economic and geographical variation in young people's housing transitions. Journal of Youth Studies, 20(1), 63-78.

Howden-Chapman, P. (2015). Home Truths: Confronting New Zealand's Housing Crisis. BWB Texts

Hulchanski, J. D. (1995). The concept of housing affordability: Six contemporary uses of the housing expenditure-to-income ratio. Housing studies, 10(4), 471-491.

Hulse, K., Reynolds, M., Stone, W., \& Yates, J. (2015). Supply shortages and affordability outcomes in the private rental sector: short and longer term trends. AHURI Final Report. Melbourne: Australian Housing and Research Institute.

Johnson, A., Howden-Chapman, P. and Eaqub, S. (2018). A Stocktake of New Zealand's Housing. Crown Copyright.

Kim, K. H. and Renaud, B. (2009). The global house price boom and its unwinding: an analysis and a commentary. Housing Studies, 24(1), 7-24.

Kuang, W. and Li, X. (2012). Does China face a housing affordability issue? Evidence from 35 cities in China. International Journal of Housing Markets and Analysis, 5(3), 272-288.

Kutty, N. K. (2005). A new measure of housing affordability: Estimates and analytical results. Housing Policy Debate, 16(1), 113-142.

Lerman, D. L., \& Reeder, W. J. (1987). The affordability of adequate housing. Real Estate Economics, 15(4), 389-404. 
Levin, A., Lin, C.-F., \& James Chu, C.-S. (2002). Unit root tests in panel data: asymptotic and finite-sample properties. Journal of Econometrics, 108(1), 1-24. https://doi.org/10.1016/S0304-4076(01)00098-7

Leybourne, S. J. (1995). Testing for unit roots using forward and reverse Dickey-Fuller regressions. Oxford Bulletin of Economics and Statistics, 57(4), 559-571.

Linneman, P. D., \& Megbolugbe, I. F. (1992). Housing affordability: Myth or reality? Urban studies, 29(3-4), 369-392.

Mattingly, K., \& Morrissey, J. (2014). Housing and transport expenditure: Socio-spatial indicators of affordability in Auckland. Cities, 38, 69-83.

Matlack, J. L. and Vigdor, J. L. (2008). Do rising tides lift all prices? Income inequality and housing affordability, Journal of Housing Economics, 17(3), 212-224.

Mayer, C. J., \& Engelhardt, G. V. (1996). Gifts, down payments, and housing affordability. Journal of Housing Research, 59-77.

McKee, K., Moore, T., Soaita, A., \& Crawford, J. (2017). 'Generation rent'and the fallacy of choice. International Journal of Urban and Regional Research, 41(2), 318-333.

Meen, G. and Andrew, M. (2008). Planning for housing in the post-Barker era: affordability, household formation, and tenure choice, Oxford Review of Economic Policy, 24(1), 79-98

Meen, G. (1999) Regional House Prices and the Ripple Effect: A New Interpretation, Housing Studies, 14(6), pp. 733-753.

Mulliner, E., Smallbone, K., \& Maliene, V. (2013). An assessment of sustainable housing affordability using a multiple criteria decision making method. Omega, 41(2), 270-279.

Murphy, L. (2004). To the market and back: Housing policy and state housing in New Zealand. GeoJournal, 59(2), 119-126.

Murphy, L. (2011). The global financial crisis and the Australian and New Zealand housing markets. Journal of Housing and the Built Environment, 26(3), 335.

Murphy, L. (2014). 'Houston, we've got a problem': The Political Construction of a Housing Affordability Metric in New Zealand. Housing Studies, 29(7), 893-909.

Murphy, L. (2016). The politics of land supply and affordable housing: Auckland's Housing Accord and Special Housing Areas. Urban Studies, 53(12), 2530-2547.

NZPC - New Zealand Productivity Commission (2012). Housing Affordability Inquiry. Wellington

Pollack, C. E., Griffin, B. A., \& Lynch, J. (2010). Housing affordability and health among homeowners and renters. American Journal of Preventive Medicine, 39(6), 515-521. 
Revington, N., \& Townsend, C. (2016). Market rental housing affordability and rapid transit catchments: Application of a new measure in Canada. Housing Policy Debate, 26(4-5), 864886.

Sayer, A. (1992). Method in Social Science: A Realist Approach. London: Hutchinson.

Sinai, T., and Souleles, N. S. (2005). Owner-occupied housing as a hedge against rent risk. The Quarterly Journal of Economics, 120(2), 763-789.

Squires, G. and Webber, D. (2019). 'House price affordability, the global financial crisis and the (ir)relevance of mortgage rates' in Regional Studies, Regional Science, Vol. 6, No. 1, pp. $405-420$

Squires, G. and White, I. (2019). 'Resilience and Housing Markets: Who is it Really For?' Land Use Policy, Vol. 81, 167-174

Squires, G. and White, D. (2020). 'Housing Affordability - Can we put the housing wealth genie back in the bottle?' Journal of Property Investment and Finance, Vol 38(1), 1-3

Stone, M. E. (2006) What is housing affordability? The case for the residual income approach. Housing Policy Debate, 17(1), 151-184

Thorns, D. C. (1988). New solutions to old problems: housing affordability and access within Australia and New Zealand. Environment and Planning A, 20(1), 71-82.

Thorns, D. (2009). Housing booms and changes to New Zealand housing affordability: The policy challenge. Journal of Asian Public Policy, 2(2), 171-189.

Voith, R.P. and Wachter, S. M. (2009) Urban growth and housing affordability: The conflict. The Annals of the American Academy of Political and Social Science, 626(1), 112131

Whitehead, C. M. (1991). From need to affordability: an analysis of UK housing objectives. Urban Studies, 28(6), 871-887.

Wood, M., Turnham, J., \& Mills, G. (2008). Housing affordability and family well-being: Results from the housing voucher evaluation. Housing Policy Debate, 19(2), 367-412. 
The connectedness of house price affordability and rental price affordability measures

Squires, G

2022-04-22

22/04/2023 - Downloaded from MASSEY RESEARCH ONLINE 